\title{
Downward fluxes of elemental carbon, metals and polycyclic aromatic hydrocarbons in settling particles from the deep Ionian Sea (NESTOR site), Eastern Mediterranean
}

\author{
C. Theodosi ${ }^{1}$, C. Parinos ${ }^{2}$, A. Gogou ${ }^{2}$, A. Kokotos ${ }^{1}$, S. Stavrakakis ${ }^{2}$, V. Lykousis ${ }^{2}$, J. Hatzianestis ${ }^{2}$, and \\ N. Mihalopoulos ${ }^{1}$ \\ ${ }^{1}$ Environmental Chemistry Processes Laboratory, Department of Chemistry, University of Crete, P.O. Box 2208, \\ 71003 Heraklion, Greece \\ ${ }^{2}$ Institute of Oceanography, Hellenic Centre for Marine Research (HCMR), 46.7 km Athens-Sounion Av., 19013 Anavyssos, \\ Attica, Greece \\ Correspondence to: N. Mihalopoulos (mihalo@chemistry.uoc.gr)
}

Received: 30 November 2012 - Published in Biogeosciences Discuss.: 21 December 2012

Revised: 23 May 2013 - Accepted: 28 May 2013 - Published: 3 July 2013

\begin{abstract}
To assess sources and major processes controlling the vertical transport of both anthropogenic and natural chemical species in a deep basin of the Eastern Mediterranean Sea (SE Ionian Sea, Nestor site), we performed chemical characterization (elemental carbon, major and trace metals and polycyclic aromatic hydrocarbons) of marine sinking particles. Sediment traps were deployed at five successive depths, 700, 1200, 2000, 3200 and $4300 \mathrm{~m}$ from the sea surface from May 2007 to October 2008. Fluxes of all measured chemical species, attributed to both natural and anthropogenic sources, exhibited minimum values from January to March 2008 and maximum from April to September 2008. Crustal matter flux from atmospheric inputs - either "freshly" deposited or stored in the surface layers - plays an important role in the temporal variability of particulate marine matter fluxes along with particulate organic carbon export, imposing ballast effects. Tracers (elemental carbon, retene) of the devastating forest fires that occurred in August 2007 in southern Greece were detected in sediment trap material from all depths with a delay of 15 days at $4300 \mathrm{~m}$, indicating a rapid and well-coupled transport of sinking particulate material between the sea-surface and deep layers of the Eastern Mediterranean Sea. This is in accordance with an evident covariance between certain compounds, suggesting common sources and/or transport mechanisms to depth. Lateral inputs of pollutants at the deepest trap $(4300 \mathrm{~m})$ are probably of importance, related to the periodic influence of deep Adriatic water at the study site.
\end{abstract}

\section{Introduction}

The Eastern Mediterranean Sea (EMS), due to its semienclosed nature, is an area subjected to intense anthropogenic pressure, resulting in pollutant discharges. The main routes are atmospheric inputs from industrialized northern and central Europe, continental runoffs, rivers and subsequent exchange between the continental shelf and slope waters (Castro-Jiménez et al., 2012; Gogou et al. 1996; Koçak et al., 2012; Mara et al., 2009; Tsapakis and Stefanou, 2005). The EMS also receives substantial amounts of petroleum discharges, mainly along shipping routes (UNEP, 2010). The on-going industrialization of Europe (in particular Eastern Europe) and southern Mediterranean countries will probably lead to increasing trends for pollutant inputs to the area.

Elemental carbon (EC), deriving from fossil fuel combustion as well as biomass burning, is emitted directly into the particulate phase and is therefore always a primary material (Pio et al., 2011). Depending on their impact on the environment metals can be classified into categories. In general, iron is nutritionally essential in ecosystems (Martin and Fitzwater, 1988; Martin et al., 1990; Theodosi et al., 2010a), together with copper and zinc, while cadmium, lead and mercury are probably the most potentially toxic metals in the environment, ubiquitous in air, water, and soils. Industrial activities may also convert the metallic forms of the metals to compounds with a resultant increase in risk for toxicity (NTP, 2002). 
Polycyclic aromatic hydrocarbons (PAHs) constitute a unique class of persistent organic pollutants abundant in the marine realm. They are included in lists of priority chemical pollutants by national and international environmental agencies (EEA-EU, EPA-US) since certain homologues present carcinogenic and mutagenic properties (Samanta et al., 2002 and references therein). PAHs' formation and release in the environment is related to various anthropogenic activities including combustion/pyrolysis of fossil fuels, biomass burning, industrial processes/outfalls, petroleum processing/transportation and accidental oil spills. However, evidence of possible biogenic contribution has been reported for individual compounds, such as perylene and retene in environmental samples (LaFlamme and Hites, 1978; Neff, 1979; Wakeham et al., 1980).

Once introduced into the marine realm primary pollutants tend to be sorbed to particles, which results in their removal from surface waters and transport to deep ocean waters via sinking particulate material. In general, particulate matter is exported to the deep sea with the downward flux of aggregates in the form of marine snow (Lampitt et al., 2001; Passow et al., 2004), which is accelerated by vertical migrations of zooplankton and the production of fast-sinking faecal pellets (Dachs et al., 2002; Fowler, 1977). Large-size particles such as faecal pellets and large aggregates (marine snow) exhibit high settling velocities $\left(50-200 \mathrm{~m} \mathrm{~d}^{-1}\right)$ and presumably collect and scavenge amounts of mineral particles too small to sediment individually (Passow, 2004). Dissolved matter can also be incorporated into the pool of marine particulate matter either actively by biological uptake (Bruland et al., 1991) or passively by scavenging (Fisher et al., 1991). Collection and analysis of sediment traps material can provide significant information regarding the processes mentioned above.

However, only few studies have quantified the temporal variability of major and trace metals flux in the Mediterranean Sea, mainly in the western basin (Heimbürger et al., 2010, 2011, 2012; Martin et al., 2009; Migon et al., 2002), while in turn the Mediterranean is rich in sediment trap studies reporting time-series data of PAH settling fluxes (Bouloubassi et al., 2006; Dachs et al. 1996; Deyme et al., 2011; Gogou, 1998; Lipiatou et al., 1993; Raoux et al., 1999; Tsapakis et al., 2006). The present study quantifies for the first time simultaneous determination of elemental carbon (EC), metals and PAH fluxes in the SE Ionian Sea, at a sediment trap line deployed in NESTOR basin (Eastern Mediterranean) from May 2007 to October 2008 at five successive water column depths (700, 1200, 2000, 3200 and $4300 \mathrm{~m}$ ). The aim was to assess major sources of primary pollutants in the area and to examine the role of seasonal changes in the composition of settling particles in their export to deep Ionian Sea basins. Delineation of the strong variability of vertical fluxes by time-series studies is essential for understanding pollutant's fate and building pollutant budgets in the
Mediterranean Sea (Marine Strategy Framework Directive 2008/56/EC).

\section{Materials and methods}

\subsection{Sampling}

Sediment trap deployment is described in detail by Stavrakakis et al. (2013). Briefly, one mooring line, NESTOR 4.5, was deployed in the SE Ionian Sea, Greece $\left(21^{\circ} 28.93^{\prime} \mathrm{E}, 36^{\circ} 32.96^{\prime} \mathrm{N}\right.$; Fig. 1) within the framework of $\mathrm{KM} 3 \mathrm{NeT}$ project. The mooring line was deployed at $4500 \mathrm{~m}$ depth instrumented with five automated time-series sediment traps (Technicap PPS3/3; Heussner et al., 1990) set at 700, $1200,2000,3200$ and $4300 \mathrm{~m}$ depth. Samples were collected on a two-week basis from 20 May 2007 to 15 October 2008. However, due to technical difficulties, samples were not obtained for the periods of 16-31 October 2007 and 16-21 April 2008 at all depths.

\subsection{Analysis}

After recovery, all samples were initially processed for the removal of swimmers (Heussner et al., 1990) and the collected particulate material was divided into aliquots for determination of elemental carbon (EC), major ( $\mathrm{Al}, \mathrm{Mn}$ and $\mathrm{Fe}$ ) and trace metals $(\mathrm{V}, \mathrm{Cr}, \mathrm{Ni}, \mathrm{Cu}, \mathrm{Cd}$ and $\mathrm{Pb})$ and polycyclic aromatic hydrocarbons. All subsamples were filtered through pre-weighted and pre-combusted $\left(450^{\circ} \mathrm{C}, 6 \mathrm{~h}\right)$ Whatman glass microfibre filters (GF/F) and were freeze-dried prior to analysis. A short description of the analytical techniques used for the analysis of major compound groups is presented below.

Elemental carbon: analysis of sediment trap material for EC content was performed using the thermal-optical transmission (TOT) technique (Birch and Cary, 1996) on a Sunset Laboratory OC/EC Analyzer, as described in detail by Theodosi et al. (2010b).

Major and trace elements: filters processed for major and trace metals were subjected to digestion with concentrated nitric acid under controlled conditions (Berghof Microwave System-2, Teflon vessels DAP - $60 \mathrm{~K}, 60 \mathrm{~mL} 40 \mathrm{bar}^{-1}$ ). After cooling to room temperature, the digested solution was transferred to an acid-cleaned polyethylene container and stored in the freezer. The solutions thus obtained were finally analyzed by Inductively Coupled Plasma Mass Spectrometry (ICP-MS, Thermo Electron X Series), following the technique described in detail by Theodosi et al. (2010c). Recoveries obtained for certified reference materials (MESS3, GBW 07313 and BCSS-1) were excellent, ranging from 90.0-104.1\% for all studied elements except Al (60\%) which was corrected accordingly. Indium (In, CPI International, S4400-1000241) was added as an internal standard to the samples before ICP-MS analysis, and calibration curves 


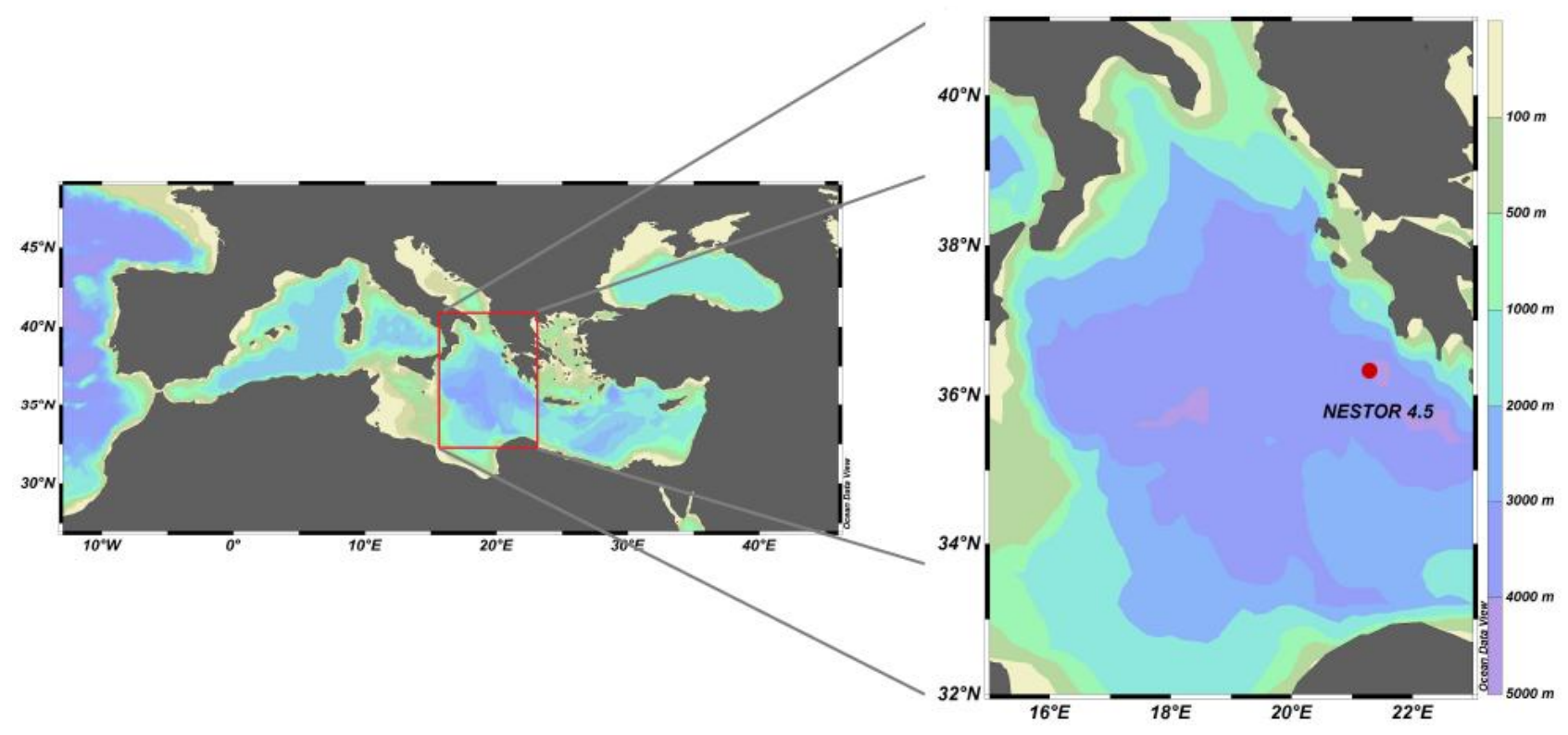

Fig. 1. Location of the sediment trap line deployed in NESTOR basin (SE Ionian Sea, Eastern Mediterranean). The map was produced using Ocean Data View (Schlitzer, 2011).

Table 1. Average fluxes and concentrations of elemental carbon, metals and PAHs measured at sediment traps deployed at 700, 1200, 2000, 3200 and $4300 \mathrm{~m}$ depth.

\begin{tabular}{|c|c|c|c|c|c|c|c|c|c|c|c|c|c|c|}
\hline & & $\mathrm{EC}$ & $\mathrm{Al}$ & $\mathrm{V}$ & $\mathrm{Cr}$ & Mn & $\mathrm{Fe}$ & $\mathrm{Ni}$ & $\mathrm{Cu}$ & $\mathrm{Cd}$ & $\mathrm{Pb}$ & $\mathrm{TPAH}_{21}$ & $\sum$ Phe & $\sum \mathrm{COMB}$ \\
\hline \multirow[t]{2}{*}{$700 \mathrm{~m}$} & $\mathrm{mg} \mathrm{m}^{-2} \mathrm{~d}^{-1}$ & $1.88 \mathrm{E}+00$ & $2.56 \mathrm{E}+00$ & $3.71 \mathrm{E}-03$ & $5.41 \mathrm{E}-03$ & $3.56 \mathrm{E}-02$ & $1.55 \mathrm{E}+00$ & $1.70 \mathrm{E}-03$ & $1.95 \mathrm{E}-03$ & $4.36 \mathrm{E}-05$ & $2.16 \mathrm{E}-03$ & $49.5^{\mathrm{a}}$ & $22.7^{\mathrm{a}}$ & $17.7^{\mathrm{a}}$ \\
\hline & $\mathrm{mg} \mathrm{g}^{-1}$ & $2.83 \mathrm{E}+01$ & $4.33 \mathrm{E}+01$ & $5.60 \mathrm{E}-02$ & $1.01 \mathrm{E}-01$ & $5.53 \mathrm{E}-01$ & $2.26 \mathrm{E}+01$ & $2.15 \mathrm{E}-02$ & $2.65 \mathrm{E}-02$ & $9.98 \mathrm{E}-04$ & $3.81 \mathrm{E}-02$ & $612^{\mathrm{b}}$ & $280^{\mathrm{b}}$ & $219^{\mathrm{b}}$ \\
\hline \multirow[t]{2}{*}{$1200 \mathrm{~m}$} & $\mathrm{mg} \mathrm{m}^{-2} \mathrm{~d}^{-1}$ & $1.72 \mathrm{E}+00$ & $2.24 \mathrm{E}+00$ & $3.40 \mathrm{E}-03$ & $5.58 \mathrm{E}-03$ & $3.24 \mathrm{E}-02$ & $1.40 \mathrm{E}+00$ & $1.44 \mathrm{E}-03$ & $2.10 \mathrm{E}-03$ & 4.42E-05 & $2.06 \mathrm{E}-03$ & & & \\
\hline & $\mathrm{mgg}^{-1}$ & $2.74 \mathrm{E}+01$ & $4.15 \mathrm{E}+01$ & $5.56 \mathrm{E}-02$ & $1.17 \mathrm{E}-01$ & $5.17 \mathrm{E}-01$ & $2.19 \mathrm{E}+01$ & $1.75 \mathrm{E}-02$ & $3.27 \mathrm{E}-02$ & $1.47 \mathrm{E}-03$ & $4.01 \mathrm{E}-02$ & & & \\
\hline \multirow[t]{2}{*}{$2000 \mathrm{~m}$} & $\mathrm{mg} \mathrm{m}^{-2} \mathrm{~d}^{-1}$ & $1.58 \mathrm{E}+00$ & $2.04 \mathrm{E}+00$ & $2.86 \mathrm{E}-03$ & $3.09 \mathrm{E}-03$ & $2.66 \mathrm{E}-02$ & $1.15 \mathrm{E}+00$ & $1.18 \mathrm{E}-03$ & $2.13 \mathrm{E}-03$ & $2.99 \mathrm{E}-05$ & $1.88 \mathrm{E}-03$ & & & \\
\hline & $\mathrm{mgg}^{-1}$ & $2.86 \mathrm{E}+01$ & $4.23 \mathrm{E}+01$ & $5.21 \mathrm{E}-02$ & $6.41 \mathrm{E}-02$ & 4.96E-01 & $2.01 \mathrm{E}+01$ & $1.52 \mathrm{E}-02$ & $3.99 \mathrm{E}-02$ & $1.31 \mathrm{E}-03$ & $4.30 \mathrm{E}-02$ & & & \\
\hline \multirow[t]{2}{*}{$3200 \mathrm{~m}$} & $\mathrm{mg} \mathrm{m}^{-2} \mathrm{~d}^{-1}$ & 4.10E-01 & $6.34 \mathrm{E}-01$ & $8.65 \mathrm{E}-04$ & $9.45 \mathrm{E}-04$ & $6.49 \mathrm{E}-03$ & $3.47 \mathrm{E}-01$ & $2.06 \mathrm{E}-04$ & $6.41 \mathrm{E}-04$ & $1.71 \mathrm{E}-05$ & $6.03 \mathrm{E}-04$ & & & \\
\hline & $\mathrm{mg} \mathrm{g}^{-1}$ & $2.37 \mathrm{E}+01$ & $4.50 \mathrm{E}+01$ & $5.62 \mathrm{E}-02$ & $6.83 \mathrm{E}-02$ & $4.26 \mathrm{E}-01$ & $2.18 \mathrm{E}+01$ & $9.19 \mathrm{E}-03$ & 3.64E-02 & $1.84 \mathrm{E}-03$ & $4.59 \mathrm{E}-02$ & & & \\
\hline \multirow[t]{2}{*}{$4300 \mathrm{~m}$} & $\mathrm{mg} \mathrm{m}^{-2} \mathrm{~d}^{-1}$ & $1.17 \mathrm{E}+00$ & $1.69 \mathrm{E}+00$ & $2.56 \mathrm{E}-03$ & $2.77 \mathrm{E}-03$ & $2.11 \mathrm{E}-02$ & $1.03 \mathrm{E}+00$ & $1.09 \mathrm{E}-03$ & $2.06 \mathrm{E}-03$ & $3.27 \mathrm{E}-05$ & $1.56 \mathrm{E}-03$ & $42.3^{\mathrm{a}}$ & $18.0^{\mathrm{a}}$ & $13.9^{\mathrm{a}}$ \\
\hline & $\mathrm{mgg}^{-1}$ & $2.45 \mathrm{E}+01$ & $4.39 \mathrm{E}+01$ & $6.22 \mathrm{E}-02$ & $8.09 \mathrm{E}-02$ & $5.15 \mathrm{E}-01$ & $2.41 \mathrm{E}+01$ & $1.84 \mathrm{E}-05$ & $5.05 \mathrm{E}-02$ & $1.06 \mathrm{E}-06$ & 4.15E-02 & $780^{\mathrm{b}}$ & $332^{\mathrm{b}}$ & $255^{\mathrm{b}}$ \\
\hline
\end{tabular}

a $\mathrm{ng} \mathrm{m}^{-2} \mathrm{~d}^{-1} ;{ }^{\mathrm{b}} \mathrm{ng} \mathrm{g}^{-1}$

were performed for each analytical batch using standard certified solutions by CPI International $\left(R^{2}=0.9999\right)$.

Polycyclic aromatic hydrocarbons: filters processed for polycyclic aromatic hydrocarbons were initially spiked with a mixture of perdeuterated internal standards $\left(\left[{ }^{2} \mathrm{H}_{10}\right]\right.$ phenanthrene, $\left[{ }^{2} \mathrm{H}_{10}\right]$ pyrene, $\left[{ }^{2} \mathrm{H}_{12}\right]$ chrysene, $\left[{ }^{2} \mathrm{H}_{12}\right]$ perylene and $\left[{ }^{2} \mathrm{H}_{12}\right]$ benzo[ghi]perylene) and were analyzed by Gas Chromatography - Mass Spectrometry (GC-MS) applying a modified protocol after Gogou et al. (1998). Details regarding the analytical procedure and instrumental analysis are described by Parinos et al. (2013). The precision of the analytical method used for PAHs determination was evaluated by analyzing the National Institute of Standards and Technology (NIST-USA) standard reference material - SRM 1941b (Organics in Marine Sediment). The determined values ranged between 93 and $106 \%$ of the certified values, while in terms of repeatability the relative standard deviation was below $5 \%$. Procedural blanks processed were found to be free of contamination.

\section{Results and discussion}

Average concentrations of individual compounds reported hereafter are time-mass flux weighted means, since the sampling interval is not constant and the temporal variability of mass flux must be taken into account (Heussner et al., 2006). In order to better assess the variability of the individual compounds reported in this study, we also consider mass flux and particulate organic carbon (POC) flux temporal and depth variability in the study area (Fig. 2a-d), which are addressed in detail by Stavrakakis et al. (2013). 
(a)

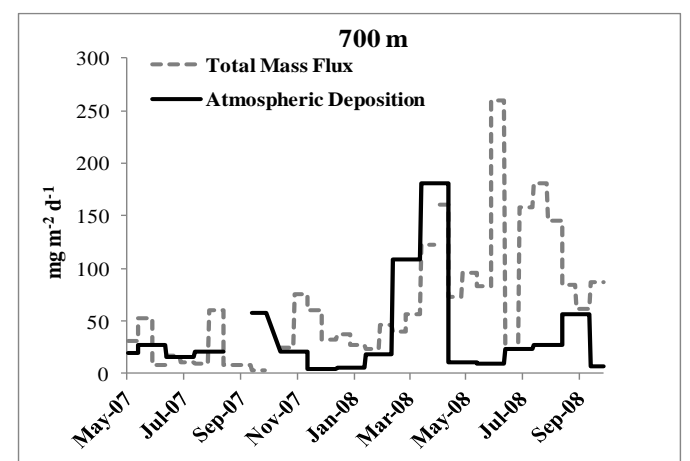

(c)

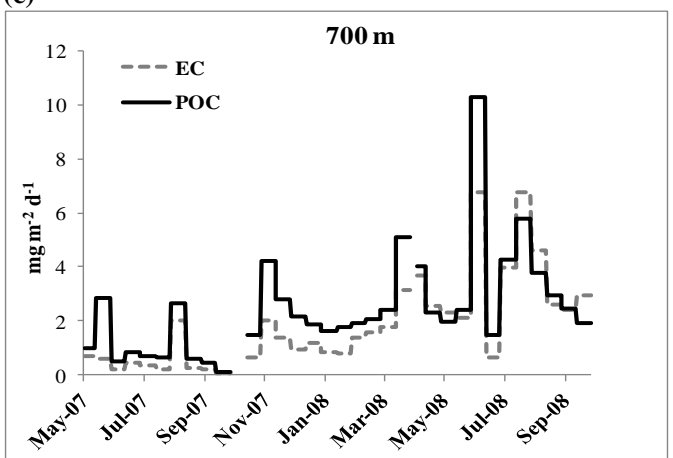

(e)

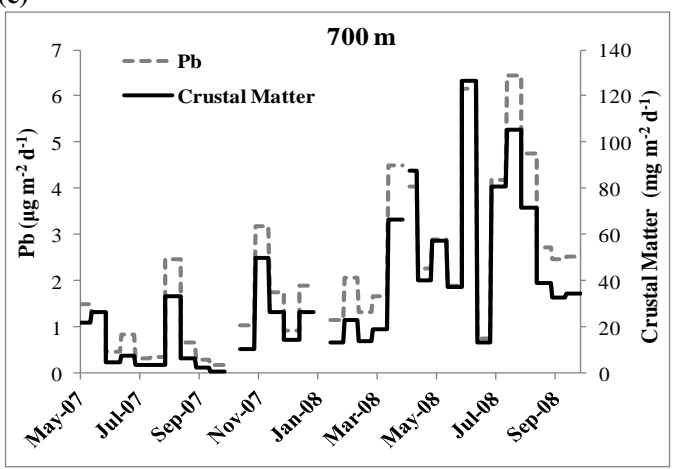

(b)

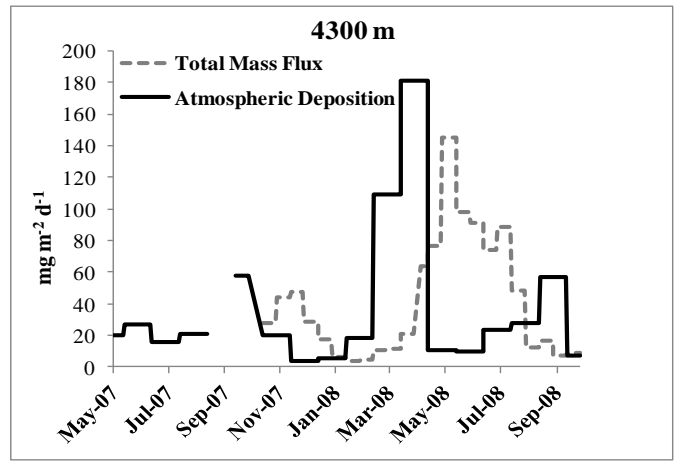

(d)

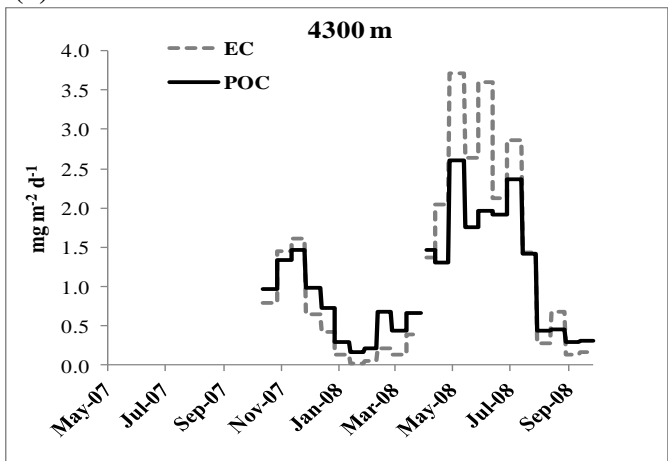

(f)

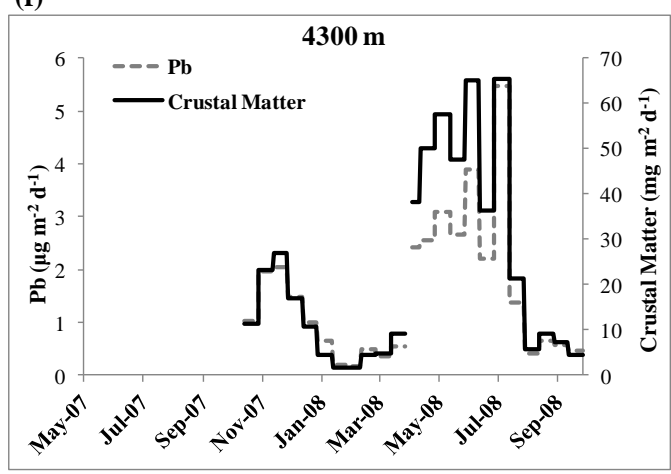

Fig. 2. Time series of total mass flux (Stavrakakis et al., 2013) and atmospheric deposition flux (a, b), particulate organic carbon (POC) and elemental carbon flux (c, d), crustal matter and lead flux (e, f), at $700 \mathrm{~m}$ and $4300 \mathrm{~m}$ depth. Fluxes of total mass, atmospheric deposition, particulate organic carbon, elemental carbon and crustal matter are expressed in $\mathrm{mg} \mathrm{m}^{-2} \mathrm{~d}^{-1}$, whilst lead flux in $\mu \mathrm{g} \mathrm{m} \mathrm{m}^{-2} \mathrm{~d}^{-1}$.

\subsection{Composition of settling particles}

\subsubsection{Elemental carbon}

EC concentrations during the studied period ranged from 7.07 to $26.8 \mathrm{mgg}^{-1}$ and fluxes from 0.03 to $6.77 \mathrm{mg} \mathrm{m}^{-2} \mathrm{~d}^{-1}$, accounting for 2.4 to $2.9 \%$ of the particulate matter flux at all depths (Table 1). The EC seasonal and depth-related flux distribution is depicted in Figs. 2c$\mathrm{d}$ and $3 \mathrm{~b}$. An almost identical variation of EC was evident between the two upper traps $(700$ and $1200 \mathrm{~m})$, the two traps deployed at 2000 and $3200 \mathrm{~m}$, while the deepest trap $(4300 \mathrm{~m})$ was characterized by a slightly different trend.
EC flux follows a decreasing trend with depth from nearly $1.88 \mathrm{mg} \mathrm{m}^{-2} \mathrm{~d}^{-1}$ at $700 \mathrm{~m}$ to $0.41 \mathrm{mg} \mathrm{m}^{-2} \mathrm{~d}^{-1}$ at $3200 \mathrm{~m}$. However, the abovementioned trend was not evident at the deepest trap $(4300 \mathrm{~m})$, most probably due to the occurrence of lateral transport of particulate matter at deep basins of the Ionian Sea (Stavrakakis et al., 2013). EC flux reached its highest values during late spring/summer periods (April to August; Figs. 2c-d and 3b), coinciding with mass flux distribution (Figs. 2a-b and 3a). In particular, the highest EC fluxes were recorded during summer 2008 at the three upper traps (average of all three traps being $3.50 \pm 2.23 \mathrm{mg}$ $\mathrm{m}^{-2} \mathrm{~d}^{-1}$, with an average for the whole sampling period of $1.73 \pm 1.65 \mathrm{mg} \mathrm{m}^{-2} \mathrm{~d}^{-1}$ ). 
(a)

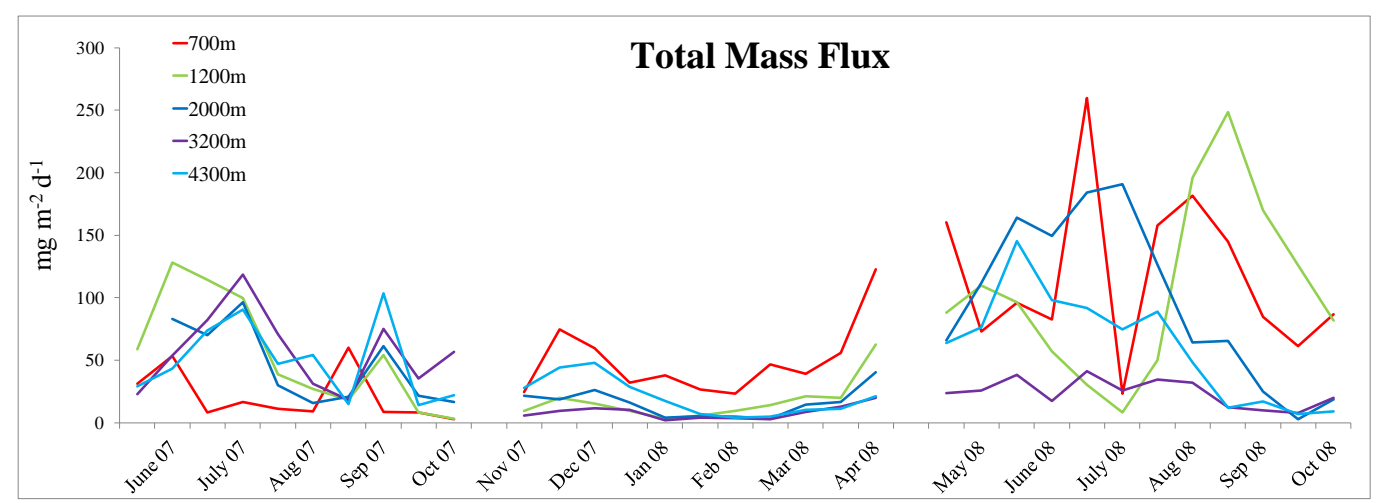

(b)

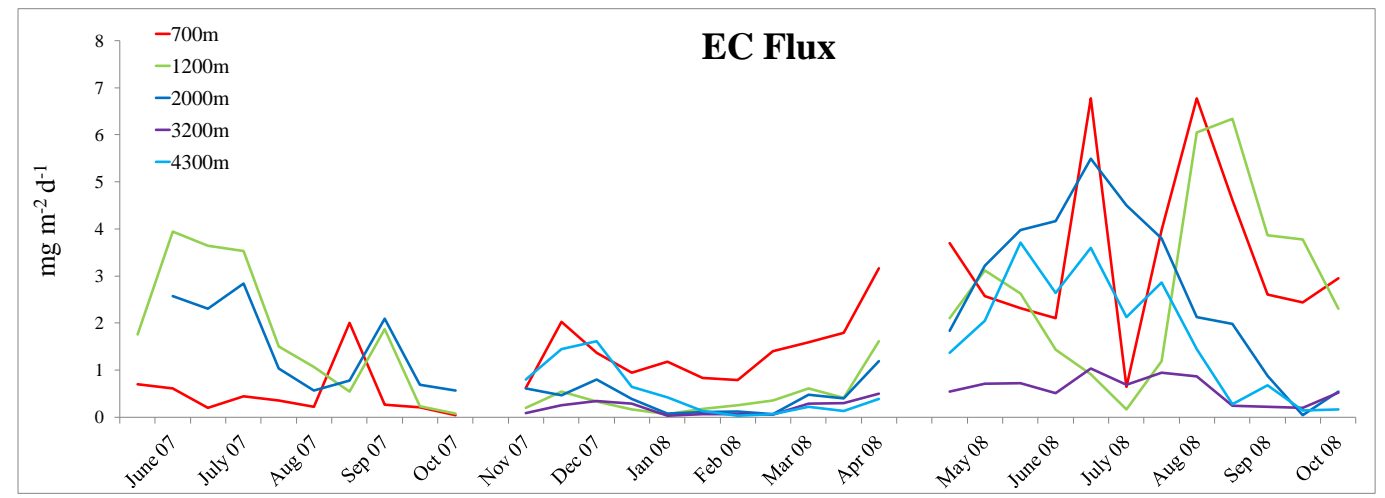

(c)

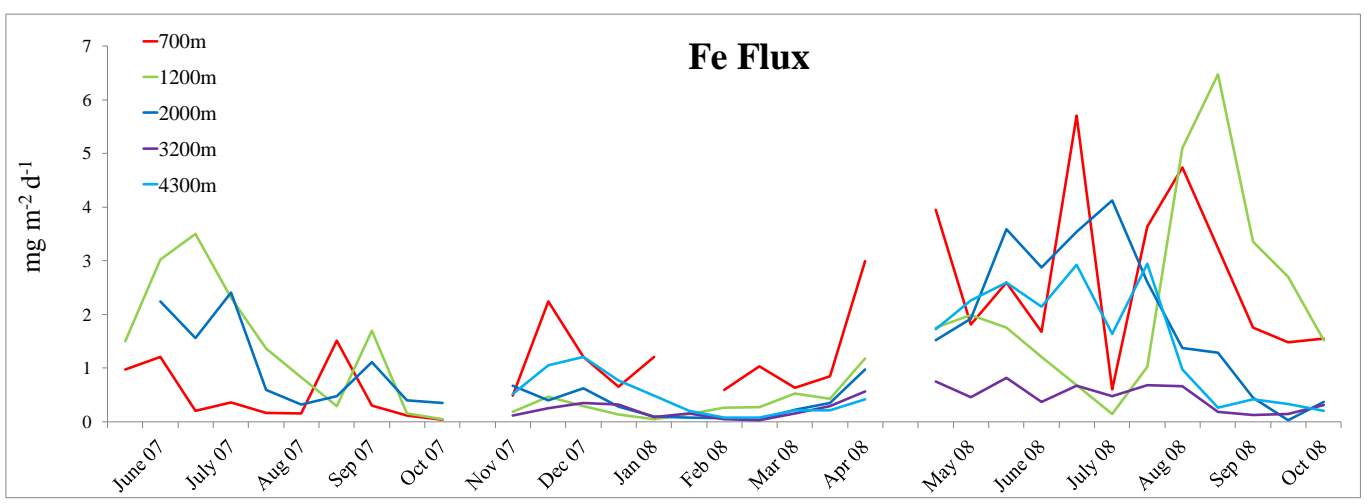

Fig. 3. Time series of total mass flux (a), elemental carbon flux (b) and iron flux (c), expressed in $\mathrm{mg} \mathrm{m}^{-2} \mathrm{~d}^{-1}$ at all five collective depths. (a) is reported by Stavrakakis et al. (2013).

\subsubsection{Major and trace metals}

Average values of major and trace metal concentrations and fluxes for the studied period are depicted in Table 1 . Crustal-derived element ( $\mathrm{Al}, \mathrm{Fe}$ and $\mathrm{Mn}$ ) concentrations and fluxes ranged from 0.15 to $107 \mathrm{mg} \mathrm{g}^{-1}$ and $4.20 \times 10^{-4}$ to $9.46 \mathrm{mg} \mathrm{m}^{-2} \mathrm{~d}^{-1}$, respectively, gradually decreasing from the shallower to the deeper traps (Fig. 3c). Highest values were generally found at $700 \mathrm{~m}$ depth ranging from 0.30 to $107 \mathrm{mg} \mathrm{g}^{-1}\left(3.28 \times 10^{-3}\right.$ to $\left.7.88 \mathrm{mg} \mathrm{m}^{-2} \mathrm{~d}^{-1}\right)$ and lowest values at $3200 \mathrm{~m}$ depth ranging from 0.15 to $102 \mathrm{mg} \mathrm{g}^{-1}$ $\left(4.20 \times 10^{-4}\right.$ to $\left.1.51 \mathrm{mg} \mathrm{m}^{-2} \mathrm{~d}^{-1}\right)$. A concomitant increase in crustal element fluxes is evident at $4300 \mathrm{~m}$ depth, in agreement with the trend observed in the case of EC. Concentrations and fluxes of anthropogenic metals $(\mathrm{V}, \mathrm{Ni}, \mathrm{Cd}$ and $\mathrm{Pb})$ at the shallower trap $(700 \mathrm{~m})$ ranged from $1.55 \times 10^{-4}$ to $8.90 \times 10^{-2} \mathrm{mg} \mathrm{g}^{-1}\left(2.57 \times 10^{-3}\right.$ to $\left.12.2 \mu \mathrm{g} \mathrm{m}^{-2} \mathrm{~d}^{-1}\right)$, decreasing, as in the case of crustal elements, with increment of collecting depth, from $700 \mathrm{~m}$ to $3200 \mathrm{~m}$, while an increase 


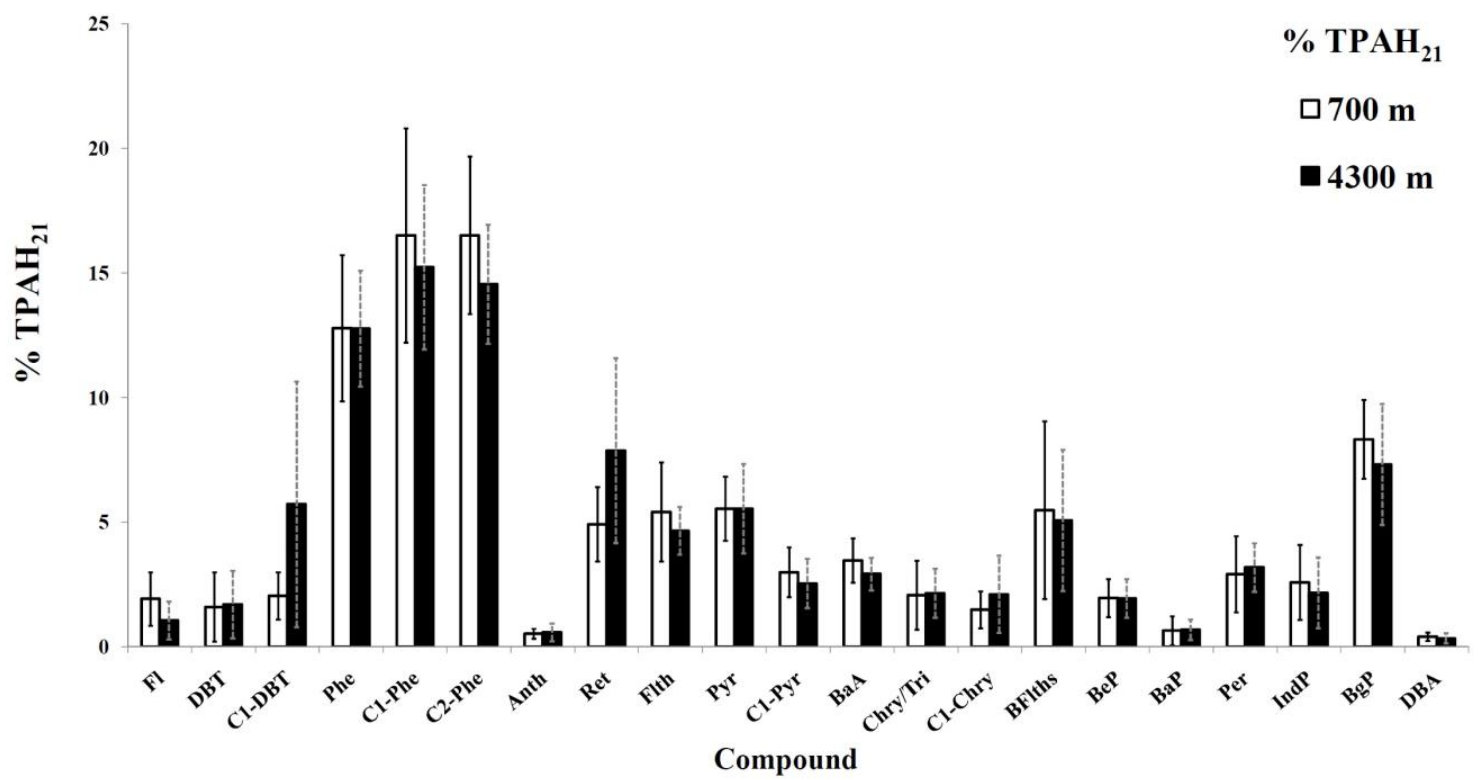

Fig. 4. Molecular profile of PAHs in sinking particles at $700 \mathrm{~m}$ and $4300 \mathrm{~m}$ depth with mean abundances normalized as percentage of the total sum of PAHs monitored (TPAH ${ }_{21}$ ) and standard errors. PAH abbreviations: Fluorene (Fl); dibenzothiophene (DBT); methyldibenzothiophenes $\left(\mathbf{C}_{\mathbf{1}}\right.$-DBT); phenanthrene (Phe); methylphenanthrenes $\left(\mathbf{C}_{\mathbf{1}}\right.$-Phe); dimethylphenanthrenes $\left(\mathbf{C}_{\mathbf{2}}\right.$-Phe); anthracene (Anth); retene $(\mathbf{R e t})$; fluoranthene (Flth); pyrene (Pyr); methylpyrenes $\left(\mathbf{C}_{\mathbf{1}}\right.$-Pyr); benz $[a]$ anthracene $(\mathbf{B a A})$; chrysene/triphenylene $(\mathbf{C h r y} /$ Tri); methylchrysenes $\left(\mathbf{C}_{\mathbf{1}}\right.$-Chry); benzo[ $\left.b / j / k\right]$ fluoranthene (BFlths); benzo[e]pyrene (BeP); benzo $[a]$ pyrene (BaP); perylene (Per); indeno[1,2,3-cd]pyrene (IndP); benzo $[g h i]$ perylene (BgP) and dibenz $[a, h]$ anthracene (DBA).

was again apparent at $4300 \mathrm{~m}$, probably due to the occurrence of lateral transport (Stavrakakis et al., 2013).

Crustal matter flux was determined using $\mathrm{Fe}$ or $\mathrm{Al}$ as tracers of crustal elements, assuming a relative ratio of $4.5 \%$ and $7.1 \%$ for each sample, respectively (Guieu et. al., 2002; Wedepohl, 1995). The average crustal content of the sediment trap material using $\mathrm{Al}$ and $\mathrm{Fe}$ as reference, $51 \%(61 \pm 27 \%)$ and $47 \%(49 \pm 13 \%)$, respectively, are in agreement with results reported for lithogenic matter by Stavrakakis et al. (2013), indicating that in the study area crustal material is an important constituent of sinking particulate material.

\subsubsection{Polycyclic aromatic hydrocarbons}

Twenty-one PAHs, parent (unsubstituted) compounds with 2-6 aromatic rings and alkyl-substituted homologues were determined in this study. $\mathrm{TPAH}_{21}$ refers hereafter to the total sum of PAHs monitored. A typical molecular profile of PAHs in sinking particles at 700 and $4300 \mathrm{~m}$ depth in the study area is presented in Fig. 4. Phenanthrene and its methyl- and dimethyl- homologues dominated the molecular profile of low molecular weight PAHs ( $\leq 3$ aromatic rings) at both depths. Their sum referred to hereafter as $\sum$ Phe, averaged $42 \pm 6 \%$ of $\mathrm{TPAH}_{21}$. As for higher MW parent PAHs ( $\geq 4$ aromatic rings) of predominantly pyrolytic origin (Neff, 1979), their sum referred to hereafter as $\sum$ COMB, accounted on average for $39 \pm 8 \%$ of $\mathrm{TPAH}_{21}$. Their pro- file was dominated by benzo[ghi]perylene primarily and benzofluoranthenes secondarily. Perylene (MW 252) is not comprised in $\sum$ COMB sum since it may have natural sources (Venkatesan, 1988). Retene was the major naturally derived PAH determined in this study (Ramdahl, 1983).

Average concentrations and fluxes of $\mathrm{TPAH}_{21}, \sum \mathrm{Phe}$ and $\sum \mathrm{COMB}$ at 700 and $4300 \mathrm{~m}$ depth are depicted in Table 1 . $\mathrm{TPAH}_{21}$ concentrations and fluxes varied significantly, ranging from 355 to $1450 \mathrm{ng} \mathrm{g}^{-1}$ and 8.87 to $211 \mathrm{ng} \mathrm{m}^{-2} \mathrm{~d}^{-1}$, respectively. $\sum$ Phe concentrations and fluxes ranged from 112 to $742 \mathrm{ng} \mathrm{g}^{-1}$ and 3.85 to $115 \mathrm{ng} \mathrm{m}^{-2} \mathrm{~d}^{-1}$, while $\sum \mathrm{COMB}$ concentrations and fluxes ranged from 159 to $475 \mathrm{ng} \mathrm{g}^{-1}$ and 2.77 to $56.4 \mathrm{ng} \mathrm{m}^{-2} \mathrm{~d}^{-1}$, respectively. PAH fluxes were higher at $700 \mathrm{~m}$, ranging from 12.6 to $211 \mathrm{ng} \mathrm{m}^{-2} \mathrm{~d}^{-1}$, than at $4300 \mathrm{~m}$ where values between 8.87 and $133 \mathrm{ng} \mathrm{m}^{-2} \mathrm{~d}^{-1}$ were recorded. In contrast, average PAH concentrations were slightly higher at $4300 \mathrm{~m}$ (Table 1). $\mathrm{TPAH}_{21}$ flux time series is presented in Fig. 5. TPAH 21 flux at $700 \mathrm{~m}$ presented maxima during the summer of 2008 with peaks at late June, late July and high fluxes throughout August, while in turn, at $4300 \mathrm{~m} \mathrm{TPAH} \mathrm{H}_{21}$ flux presented maxima at late spring, late April and throughout May 2008.

\subsection{Comparison with literature data}

Table 2a, b presents fluxes and concentrations of major and trace metals and PAHs, respectively, reported in previous sediment trap deployments in the Mediterranean and Black 


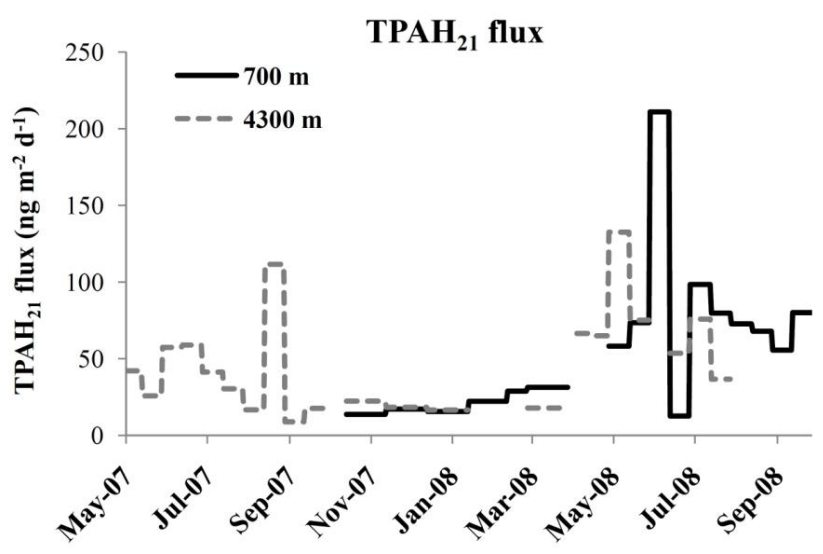

Fig. 5. Time series of $\mathrm{TPAH}_{21}$ flux at $700 \mathrm{~m}$ and $4300 \mathrm{~m}$ depth in the study area.

Sea regions. Fluxes of major and trace metals have been previously reported for the Eastern Mediterranean Sea by Theodosi et al. (2010c), for a sediment trap deployment at $1715 \mathrm{~m}$ covering the period from 1999 to 2005. In the aforementioned study only average values for the $6 \mathrm{yr}$ span period were reported. However, fluxes reported in this study are comparable and in fact lower (factor 0.3 to 0.6 ) for the anthropogenic metals $(\mathrm{V}, \mathrm{Cr}, \mathrm{Cu}, \mathrm{Cd}$ and $\mathrm{Pb})$, while equal for the crustal elements (Mn and $\mathrm{Fe}$ ). Fluxes of major and trace metals reported in this study can also be compared to previous timeseries studies in the Western Mediterranean Sea (Roussiez et al., 2012; Martin et al., 2009; Migon et al., 2002). Despite the possibility of interannual variability, fluxes reported in this study for major and trace elements are consistent to those reported for Ligurian Sea (DYFAMED, Martin et al., 2009; Migon et al., 2002), as well as with concentrations reported for the Gulf of Lions (Roussiez et al., 2012). Settling flux data from this work are also compared (Table 2a) with data recently reported for the Black Sea region (Theodosi et al., 2013), which is characterized by different hydrological and biological features. Anthropogenic metal fluxes $(\mathrm{Ni}, \mathrm{Cu}$ and $\mathrm{Pb}$ ) at the Black Sea were higher by a factor of 4 and in the case of $\mathrm{Cd}$ by a factor of 6 , whilst no significant difference was observed for the elements $\mathrm{Al}, \mathrm{Mn}$ and $\mathrm{Fe}$.

As for PAHs (Table 2b), concentrations and fluxes reported in this study are comparable to those reported for the open Western Mediterranean Sea (Bouloubassi et al., 2006) and Alboran Sea (Dachs et al., 1996), higher than those previously reported for the Eastern Mediterranean Sea (Gogou, 1998; Tsapakis et al., 2006), lower than those recently reported for the Black Sea (Parinos et al., 2013) and considerably lower than those reported for Ligurian Sea (DYFAMED, Deyme et al., 2011; Lipiatou et al., 1993) and French coast (Raoux et al., 1999).

\subsection{Sources of natural and anthropogenic compounds in the deep Ionian Sea}

The composition of the settling particulate matter described above reflects contributions from both natural and anthropogenic sources in the study site.

Elemental carbon (EC) which is considered to be a good tracer of combustion processes (fossil fuel combustion, namely urban emissions from road transport as well as biomass burning) is emitted directly in the particulate phase and is therefore always primary material (Pio et al., 2011). Metals such as $\mathrm{Al}, \mathrm{Fe}, \mathrm{Cu}$ and $\mathrm{Cr}$ usually originate from soil dust or mechanical abrasion processes. $\mathrm{Cd}, \mathrm{V}$ and $\mathrm{Ni}$ are generally considered to have anthropogenic emission sources, such as vehicular, industrial emissions and resuspension (Lough et al., 2005; Salma and Maenhaut, 2006; Sternbeck et al., 2002). Specifically V and Ni have been used as fuel-oil combustion tracers (Lough et al., 2005). Furthermore it has been reported that $\mathrm{Cu}$ derived from brake linings (Weckwerth, 2001), while $\mathrm{Fe}$ and $\mathrm{Cu}$ are predominant elements identified in the debris, regardless of the material used in the brake lining (Adachi and Tainosho, 2004; Lough et al., 2005).

In order to determine the prevailing source of major and trace elements in the study area, the enrichment factor (EF) of all elements relative to the Saharan end-member was calculated, using $\mathrm{Fe}$ as crustal marker (Chester et al., 1990). By convention, arbitrary average EF values lower than 10 is taken as an indication that an element has a predominant reference material source. In contrast, EF higher than 10 are considered to indicate that a significant proportion of an element has a non-reference material source. For our data the low EF $(<10)$ for all studied elements and depths indicates significant contribution from a crustal source, as previously documented in sediment trap samples in the northwestern Mediterranean by Roussiez et al. (2012). It is well documented that the EMS is occasionally influenced by Sahara dust events from northern Africa, containing natural crustal material (Guerzoni et al., 1999; Herut et al., 2005; Jickells, 1995; Ridame and Guieu, 2002; Saydam and Senyuva, 2002).

In the PAHs family, the predominance of alkylated phenanthrenes over the unsubstituted compound within the phenanthrene series, followed by the elevated abundance of methyl-alkylated homologues monitored within the dibenzothiophene, pyrene and chrysene series, and the presence of parent compounds with $\geq 4$ aromatic rings (Fig. 4 ), indicate a contribution from both unburned fossil fuels (petroleum) and combustion/pyrolytic PAHs in shallow and deep waters of the study area (Neff, 1979; Wakeham et al., 1980). Moreover, diagnostic ratios have been used to infer conclusions regarding the origin and different sources of PAHs at both depths (Yunker et al., 2002). The Flth/(Flth + Pyr), IndP/(IndP + $\mathrm{BgP}), \mathrm{BaA} /(\mathrm{BaA}+$ Chry $)$ and $1.7 /(1.7+2.6) \mathrm{C}_{2}$-Phe ratios (Fig. 6a-b) evidence the presence of PAHs deriving from 


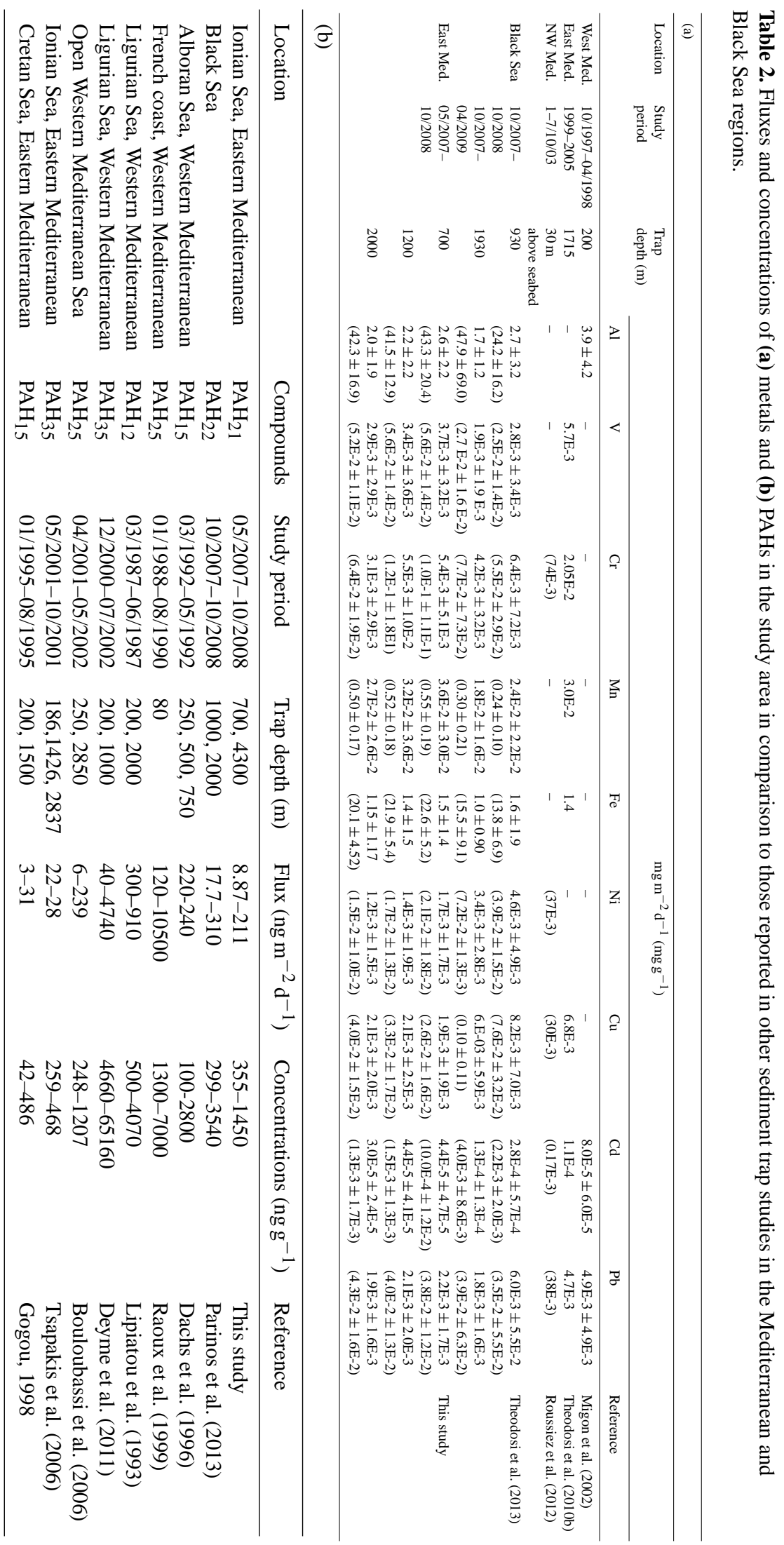


Table 3. Pearson correlation coefficients $(r)$ between major and trace metals and EC concentrations $\left(\mathrm{mg} \mathrm{g}^{-1}\right)$ determined at $700 \mathrm{~m}$ and $4300 \mathrm{~m}$ depth, respectively.

\begin{tabular}{|c|c|c|c|c|c|c|c|c|c|c|}
\hline $\begin{array}{l}700 \mathrm{~m} \\
\left(\mathrm{mg} \mathrm{g}^{-1}\right)\end{array}$ & $\mathrm{Al}$ & V & $\mathrm{Cr}$ & $\mathrm{Mn}$ & $\mathrm{Fe}$ & $\mathrm{Ni}$ & $\mathrm{Cu}$ & $\mathrm{Cd}$ & $\mathrm{Pb}$ & EC \\
\hline $\mathrm{Al}$ & 1.00 & & & & & & & & & \\
\hline V & & 1.00 & & & & & & & & \\
\hline $\mathrm{Cr}$ & & & 1.00 & & & & & & & \\
\hline $\mathrm{Mn}$ & & 0.77 & & 1.00 & & & & & & \\
\hline $\mathrm{Fe}$ & & 0.93 & & 0.71 & 1.00 & & & & & \\
\hline $\mathrm{Ni}$ & & 0.48 & 0.52 & 0.48 & 0.45 & 1.00 & & & & \\
\hline $\mathrm{Cu}$ & & & & 0.57 & & 0.69 & 1.00 & & & \\
\hline $\mathrm{Cd}$ & 0.81 & & & & & & & 1.00 & & \\
\hline $\mathrm{Pb}$ & 0.71 & 0.47 & & 0.57 & & & & 0.64 & 1.00 & \\
\hline $\mathrm{EC}$ & & & & & & & & & & 1.00 \\
\hline $\begin{array}{l}4300 \mathrm{~m} \\
\left(\mathrm{mg} \mathrm{g}^{-1}\right)\end{array}$ & $\mathrm{Al}$ & $\mathrm{V}$ & $\mathrm{Cr}$ & $\mathrm{Mn}$ & $\mathrm{Fe}$ & $\mathrm{Ni}$ & $\mathrm{Cu}$ & $\mathrm{Cd}$ & $\mathrm{Pb}$ & EC \\
\hline $\mathrm{Al}$ & 1.00 & & & & & & & & & \\
\hline V & 0.85 & 1.00 & & & & & & & & \\
\hline $\mathrm{Cr}$ & 0.71 & & 1.00 & & & & & & & \\
\hline $\mathrm{Mn}$ & 0.78 & 0.90 & & 1.00 & & & & & & \\
\hline $\mathrm{Fe}$ & 0.74 & 0.97 & & 0.85 & 1.00 & & & & & \\
\hline $\mathrm{Ni}$ & & & & & & 1.00 & & & & \\
\hline $\mathrm{Cu}$ & 0.60 & 0.65 & & 0.84 & 0.54 & & 1.00 & & & \\
\hline $\mathrm{Cd}$ & 0.86 & & 0.66 & & & & & 1.00 & & \\
\hline $\mathrm{Pb}$ & 0.88 & 0.84 & 0.73 & 0.83 & 0.74 & & 0.67 & 0.63 & 1.00 & \\
\hline EC & & & & & & 0.71 & & & & 1.00 \\
\hline
\end{tabular}

multiple sources such as wood, coal and petroleum combustion, along with petroleum residues during the summer of 2008. The presence of retene reflects inputs from terrestrial plants, mainly conifer resins (Wakeham et al., 1980) or inputs related to pinewood combustion (Ramdahl, 1983).

To assess common sources of major and trace metals in the study area, correlation analysis was performed both in terms of their concentrations and fluxes. In terms of concentrations (Table 3), statistically significant correlations $(p<$ 0.01 ) are observed between elements of same origin but also between elements of different origin. More specifically, in terms of concentrations for two indicative water depths, 700 and $4300 \mathrm{~m}$, crustal species ( $\mathrm{Al}$ and $\mathrm{Fe}$ ) are not significantly correlated at $700 \mathrm{~m}$ depth, while in turn a strong correlation was observed in the deepest trap $(r=0.74)$. The latter is probably attributed to the occurrence of lateral transport of sedimentary material and/or resuspension of bottom sediments. Supportive to the above, elements of "mixed", crustal and anthropogenic origin reveal considerable correlation at the deepest trap (Fe vs. V, Cu, Pb; $r>0.54$ and Al, Fe vs. V, $\mathrm{Mn} ; r>0.78)$. However, statistically significant correlations are observed between $\mathrm{Fe}$ and anthropogenic species $(\mathrm{V}, \mathrm{Ni})$ at $700 \mathrm{~m}$, pointing to a relatively enhanced contribution of anthropogenic $\mathrm{Fe}$ at this depth. In the case of $\mathrm{V}$ and $\mathrm{Ni}$, which have been used as fuel-oil combustion tracers (Lough et al.,
2005), a comparatively good correlation was observed for the trap deployed at $700 \mathrm{~m}(r=0.48$; Table 3$)$. There was no significant correlation at the deepest trap providing evidence that the atmosphere is an important pathway, demonstrating residual oil combustion as a contributing source.

As for PAHs, concentrations of parent compounds with $\geq 4$ aromatic rings ( $\sum \mathrm{COMB}$ ) correlate significantly with EC concentrations at $700 \mathrm{~m}$ depth $(r=0.68, p<0.01)$. This result is consistent with the strong association of PAH deriving from pyrolytic/combustion sources to fine combustion particles (char and soot elemental carbon) that protect them from degradation during transport from initial sources, via both atmospheric and aquatic pathways, and sinking through the water column, in agreement with earlier reports (CastroJimenez et al., 2012; Dachs and Eisenreich 2000; Gustafsson et al., 1997; Parinos et al., 2013; Tsapakis et al., 2006; Yunker et al., 2002). The lack of correlation between $\sum$ COMB-EC concentrations at $4300 \mathrm{~m}$ probably indicates a decoupling between surface and deep waters in the study area. However lateral inputs of particulate matter at this depth (i.e. Adriatic deep water, see Stavrakakis et al., 2013 and Sect. 3.4 below) should be considered as a possible masking factor for $\sum$ COMB-EC concentrations association.

However, when fluxes of all elements, regardless of their origin, are strongly and significantly $(p<0.01)$ 
(a)

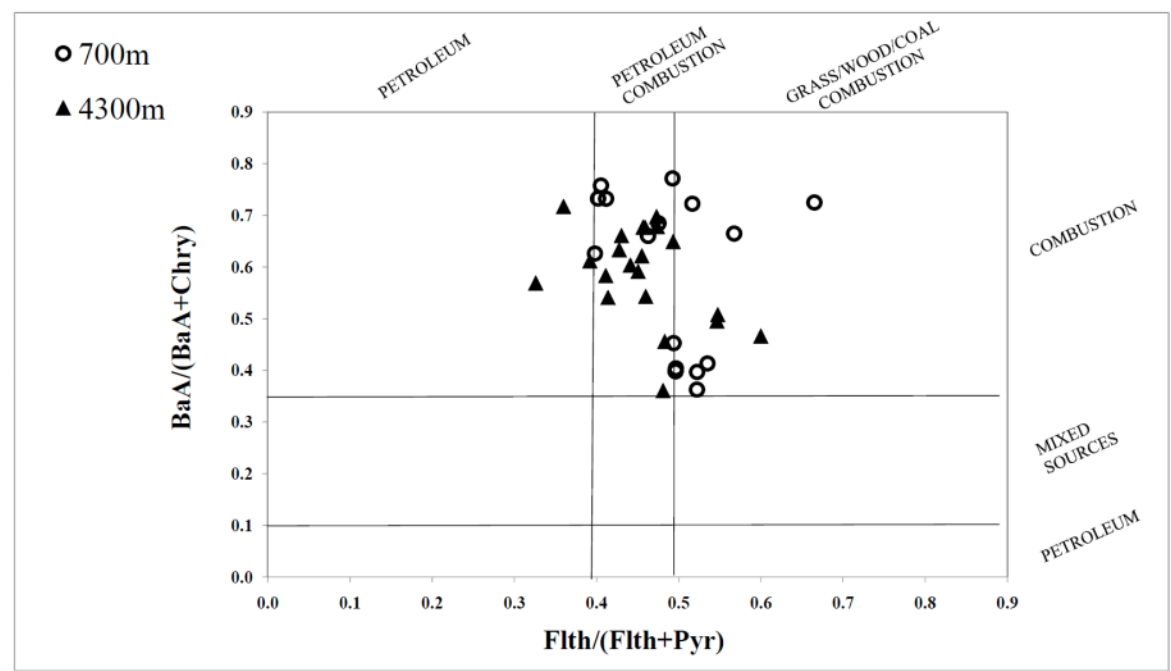

(b)

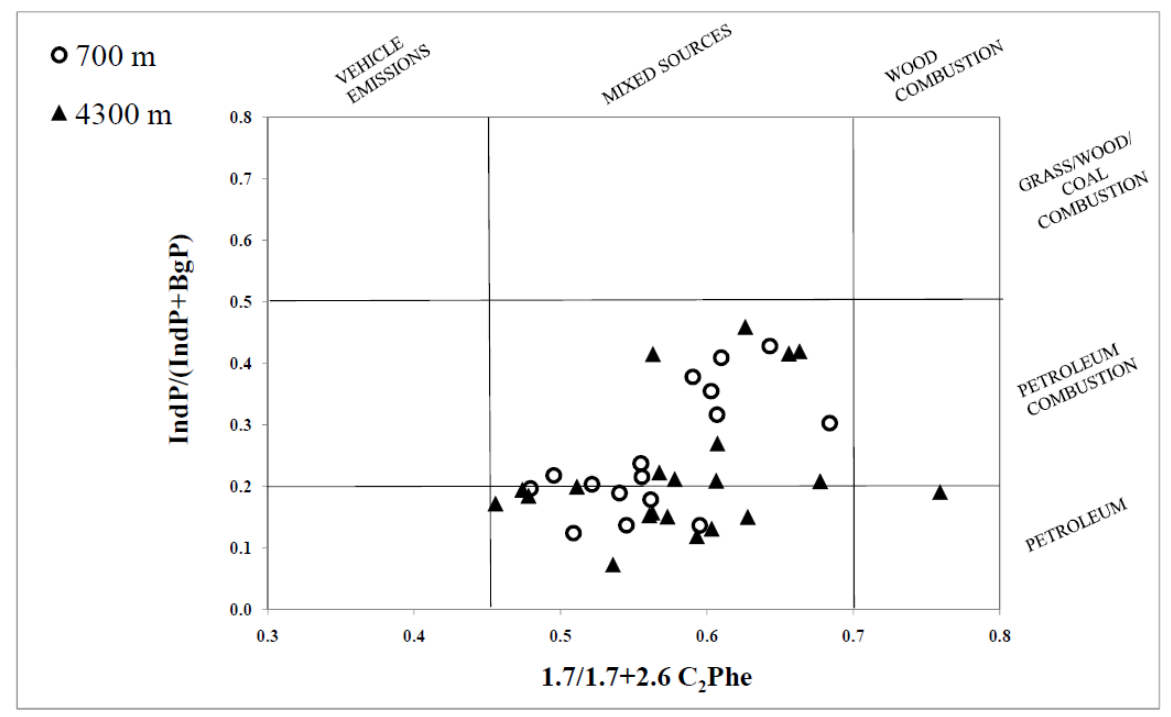

Fig. 6. The $\mathrm{BaA} /(\mathrm{BaA}+$ Chry $)$ vs. Flth/(Flth $+\mathrm{Pyr})\left(\right.$ a) and $\mathrm{IndP} /(\mathrm{IndP}+\mathrm{BgP})$ vs. $1.7 /(1.7+2.6) \mathrm{C}_{2}$-Phe (b) PAHs diagnostic ratios co-plots at $700 \mathrm{~m}$ and $4300 \mathrm{~m}$ depth, along with literature guidelines for specific sources (Yunker et al., 2002).

intercorrelated, it suggests a common transport mechanism in the deep layers of the Ionian Sea (Nestor site). This point is discussed in detail below in Sect. 3.5.

\subsection{Transport of organic pollutants to deep basins of the Eastern Mediterranean Sea during massive forest fires of summer 2007 in Greece}

Strong winds, heat waves and extended droughts in several areas across Greece during the summer of 2007, resulted in the breakout of severe forest fires which devastated a to- tal of 670000 acres $\left(2700 \mathrm{~km}^{2}\right)$ of forest, olive groves and farmlands. $370000\left(1500 \mathrm{~km}^{2}\right)$ of the total 670000 acres of forests were burnt in western and southern Peloponnese, Southern Greece, from 23-30 August 2007. Turquety et al. (2009) reported that the $\mathrm{CO}$ burden emitted during those 7 days of the Peloponnese fires (estimated at about $0.321 \mathrm{Tg}$ $\mathrm{CO}$ ) accounted for approximately $40 \%$ of the expected annual anthropogenic emissions for this region. Satellite images (Fig. 7) clearly show the existence of fire plumes to the southwest, directly over the sampling site, across the 
Table 4. Retene, pimanthrene (ng g $\mathrm{g}^{-1}$ and $\left.\% \mathrm{TPAH}_{21}\right)$ and $\mathrm{TPAH}_{21}$ flux for $4300 \mathrm{~m}$ depth and EC fluxes $\left(\mathrm{mg} \mathrm{m}^{-2} \mathrm{~d}^{-1}\right)$ and concentrations $\left(\mathrm{mg} \mathrm{g}^{-1}\right)$ for the traps deployed at 700, 1200 and $2000 \mathrm{~m}$ depth during and after the Peloponnese fires in August 2007.

\begin{tabular}{|c|c|c|c|c|c|}
\hline & Depth & $01-15 / 08 / 2007$ & $\begin{array}{r}16-31 / 08 / 2007 \\
\text { (fires period) }\end{array}$ & $01-15 / 09 / 2007$ & $16-30 / 09 / 2007$ \\
\hline Retene $\left(\mathrm{ng} \mathrm{g}^{-1}\right)$ & $4300 \mathrm{~m}$ & 21.8 & 39.5 & 128 & 58.4 \\
\hline Retene $\left(\% \mathrm{TPAH}_{21}\right)$ & $4300 \mathrm{~m}$ & 3.9 & 3.6 & 11.9 & 9.2 \\
\hline Pimanthrene (ng g ${ }^{-1}$ ) & $4300 \mathrm{~m}$ & 9.06 & 15.1 & 24.3 & 10.9 \\
\hline Pimanthrene $\left(\% \mathrm{TPAH}_{21}\right)$ & $4300 \mathrm{~m}$ & 1.11 & 1.36 & 2.35 & 1.73 \\
\hline $\mathrm{TPAH}_{21}$ flux $\left(\mathrm{ng} \mathrm{m}^{-2} \mathrm{~d}^{-1}\right)$ & $4300 \mathrm{~m}$ & 30.4 & 16.6 & 112 & 8.87 \\
\hline $\mathrm{EC}\left(\mathrm{mg} \mathrm{m}^{-2} \mathrm{~d}^{-1}\right)$ & $2000 \mathrm{~m}$ & 0.6 & 0.8 & 2.1 & 0.7 \\
\hline $\mathrm{EC}\left(\mathrm{mg} \mathrm{g}^{-1}\right)$ & $2000 \mathrm{~m}$ & 35.8 & 37.2 & 34.1 & 31.5 \\
\hline $\mathrm{EC}\left(\mathrm{mg} \mathrm{m}^{-2} \mathrm{~d}^{-1}\right)$ & $1200 \mathrm{~m}$ & 1.1 & 0.5 & 1.9 & 0.2 \\
\hline $\mathrm{EC}\left(\mathrm{mg} \mathrm{g}^{-1}\right)$ & $1200 \mathrm{~m}$ & 39.8 & 29.7 & 34.7 & 27.1 \\
\hline $\mathrm{EC}\left(\mathrm{mg} \mathrm{m}^{-2} \mathrm{~d}^{-1}\right)$ & $700 \mathrm{~m}$ & 0.2 & 2.0 & 0.3 & 0.2 \\
\hline $\mathrm{EC}\left(\mathrm{mgg}^{-1}\right)$ & $700 \mathrm{~m}$ & 24.6 & 33.4 & 30.3 & 24.2 \\
\hline
\end{tabular}

* Results are not available for PAHs in the upper trap, while for EC in the deepest trap.

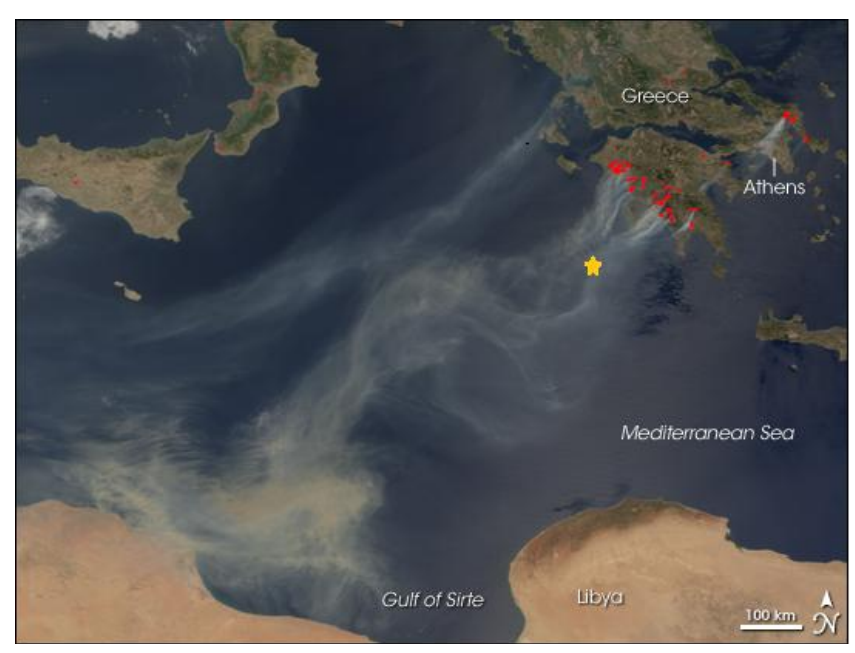

Fig. 7. Aqua-MODIS sensor satellite image above southern Greece for the 26 August 2007 showing aerosol transport from the burning Peloponnese over the sampling site and across the Mediterranean Sea. Adapted from NASA's earth observatory (http: //earthobservatory.nasa.gov/IOTD/view.php?id=7996). The orange dot indicates the location of the mooring line, NESTOR 4.5.

Mediterranean towards Libya and Tunisia in North Africa, as the last week of August 2007 was characterized by strong northeasterly winds above Greece (Turquety et al., 2009).

Stavrakakis and Lykousis (2011) reported that during the Peloponnese fires period, a peak in total mass flux was recorded at $700 \mathrm{~m}$, which was also recorded after 15 days at all depths. The authors concluded that this peak was due to the atmospheric transport and deposition of elemental carbon emitted from the fire, as indicated by the presence of microscope visible charcoal fragments. As verified by our results, such a peak for the EC flux was recorded for the trap at $700 \mathrm{~m}$ (Table 4). More specifically, EC flux presented a clear maxima for the period from 16 to 31 August 2007 (Figs. 2c-d and 3b), $2 \mathrm{mg} \mathrm{m}^{-2} \mathrm{~d}^{-1}$, value which is a factor of 8-9 times higher compared to the value measured before and after this sampling period (01-15 August and 01-15 September; $0.2 \mathrm{mg} \mathrm{m}^{-2} \mathrm{~d}^{-1}$ and $0.3 \mathrm{mg} \mathrm{m}^{-2} \mathrm{~d}^{-1}$, respectively). This increase in EC flux was also clearly observed at $1200 \mathrm{~m}$ and $2000 \mathrm{~m}$ with a 15-day delay. At the same time, the average EC mass ratio at $700 \mathrm{~m}$ was equal to $33.4 \mathrm{mg} \mathrm{g}^{-1}$ during the period of forest fires (16-31 August 2007), increased by a factor of 1.1-1.4 compared to the periods of 01-15 August and 01-15 September of the same year. Similar tendencies with a 15-day delay can be observed at 1200 and $2000 \mathrm{~m}$.

A number of facts inferring from the analysis of PAHs further support the above statement (Table 4). Retene is a common diterpenoid constituent of conifer resins in temperate climates (Laflamme and Hites, 1978) and is rapidly formatted during pinewood combustion (Ramdahl, 1983). Thus, forest soils and forest fires constitute the principal sources of retene in the marine environment through riverine inputs and atmospheric deposition (Lipiatou and Saliot, 1991). Retene's concentration showed similar trends not only as an absolute concentration but also as a percentage of the total sum of PAHs $\left(\mathrm{TPAH}_{21}\right)$. At $4300 \mathrm{~m}$ depth, concentration of retene increased from $39.5 \mathrm{ng} \mathrm{g}^{-1}$ for the period from 1631 August 2007 to $128 \mathrm{ng} \mathrm{g}^{-1}$ in the following days (0115 September 2007). The percent of retene for $\mathrm{TPAH}_{21}$ increased from $4 \%$ to $12 \%$ for the same period.

Pimanthrene, another common diterpenoid constituent of plant resins, especially from coniferous trees, showed similar trends with retene (Table 4). At $4300 \mathrm{~m}$ depth, concentration of pimanthrene increased from $15.1 \mathrm{ng} \mathrm{g}^{-1}$ for the period from 16-31 August 2007 to $25.3 \mathrm{ng} \mathrm{g}^{-1}$ in the following days (01-15 September 2007). Its percent for $\mathrm{TPAH}_{21}$ also increased from $1.4 \%$ to $2.4 \%$. $\mathrm{TPAH}_{21}$ flux (Fig. 5), following the total mass flux trend, increased from 16.6 to 
$112 \mathrm{ng} \mathrm{m}^{-2} \mathrm{~d}^{-1}$ at $4300 \mathrm{~m}$ during the aforementioned periods.

The above indicate that compounds deriving from forest fire emissions undergo a very rapid and significant transport and deposition even to the deepest basins of the Eastern Mediterranean Sea, through atmospheric deposition of wood and grass charcoal elemental (black) carbon emitted from burning plants tissue which provide matrices stable enough to trap and stabilize PAHs, allowing their efficient transport to deep basins (Yunker et al., 2011 and references therein). Indeed transport time ranged from a few days at the upper trap $(700 \mathrm{~m})$ to less than 15 days down to $4300 \mathrm{~m}$ depth, indicating a strong coupling of atmospheric deposition and settling fluxes for this period.

An important outcome of the massive 2007 summer forest fires that must be also taken into consideration is that the high values of the Flth/(Flth + Pyr) ratio (>0.50) that were recorded at both $700 \mathrm{~m}$ and $4300 \mathrm{~m}$ of depth during the following winter 2008 period indicating grass, wood and coal combustion sources, could probably be attributed to increased continental run-offs and/or river discharges and subsequent off-shelf export of PAHs accumulated in soils of burned forest areas, as a result of soil leaching and extended erosion during winter period rainfalls.

\subsection{Seasonal, depth-related distribution of natural and anthropogenic compounds and their driving parameters in deep Ionian Sea}

As discussed in Sect. 3.3, fluxes of all studied elements, regardless of their origin, are strongly and significantly $(p<$ 0.01 ) intercorrelated, suggesting a common transport mechanism in the deep layers of the Ionian Sea (Nestor site). Figs. $2 a-b$ and $3 a$ clearly show that total mass flux of particulate matter (reported by Stavrakakis et al., 2013) at the 4 upper traps $(700,1200,2000$ and $3200 \mathrm{~m}$ ) is characterized by a slight decrease with increasing depth. Comparison of the seasonal patterns reveals that similar periods of high and low fluxes are observed for all measured natural and anthropogenic compounds in our study (Figs. 2-5) and major biogeochemical species (Stavrakakis et al., 2013). However, the aforementioned observation was stronger and more evident at the 4 upper traps (Fig. 2). In contrast, the seasonal decrease in the total mass flux recorded at $4300 \mathrm{~m}$ did not follow the pattern described for the 4 upper traps, in agreement with trends observed for EC, major and trace metals and PAHs. Stavrakakis et al. (2013) attribute this behavior to lateral transport of particulate matter occurring at this depth, due to the formation of deep water masses in the Adriatic Sea, which are exported by means of bottom-arrested currents toward the abyssal layers of the Ionian basin, flowing in an eastward path all the way towards the eastern Levantine basin.

Mass flux temporal variability in the study area is subjected to strong seasonality which is driven by the succes- sion of plankton communities in the overlying surface layer. According to this, export patterns associated to biologically driven processes are expressed by particulate organic carbon (POC), carbonates and biogenic Si fluxes (Stavrakakis et al., 2013). These authors also suggested that atmospheric dust inputs, witnessed by the enhanced fluxes of the lithogenic fraction during certain periods of the time-series flux experiment, are also crucial. Ternon et al. (2010) have also emphasized the important role of occasional extreme Saharan events, and the usual winter convection, in the carbon export to the deep Mediterranean Sea. These authors, by performing simultaneous measurements of atmospheric deposition and sinking particles in the Ligurian Sea (NW Mediterranean) between 2003 to 2007, conclude that the strongest POC fluxes were concomitant with large increases in lithogenic material originating either from recent Sahara dust events, or "old" Saharan dust "stored" in the upper water column or finally from material originating from riverine flooding.

Figure $2 \mathrm{a}-\mathrm{b}$ report time series of marine and atmospheric deposition mass fluxes. Two maxima of marine mass fluxes are clearly evident. The first one occurred in April 2008 concurrent with an important atmospheric deposition event. The aforementioned maximum in mass flux was recorded for all 5 collective depths with almost the same amount of material at the shallower and deepest one, with a time lag of 15-30 days. Crustal material acting as ballast could be an important driver for this rapid transfer of material down to $4300 \mathrm{~m}$. Theodosi et al. (2013) have shown that in the Black Sea atmospheric deposition of dust can entirely account for the measured levels of crustal material in sediment traps. Deposition measurements on the island of Crete showed that during 2008, large sporadic inputs of Saharan dust events were $38 \%$ higher compared to 2007 (Mihalopoulos and Theodosi, unpublished data). As measurements on Crete have a more regional than local significance, this result concerns the majority of the Eastern Mediterranean basin. The increase in dust deposition (8.8 to $14.1 \mathrm{~g} \mathrm{~m}^{-2} \mathrm{yr}^{-1}$, in 2007 and 2008 , respectively) could explain the increase in mass flux between 2007 and 2008 by almost the same amount, associated with an increase in fluxes of all analyzed elements.

The second maximum in marine mass fluxes (Fig. 2a-b), from May 2008 to September 2008, is not coinciding with any major atmospheric deposition event indicating the existence of a triggering process other than dust deposition. Stavrakakis et al. (2013) by using time series of salinity profiles, obtained from the CT (conductivity, temperature) array in the nearby observational buoy of the Poseidon system (www.poseidon.hcmr.gr) showed an upwelling of intermediate waters of Cretan/Levantine origin, reaching the euphotic layer. This upwelling may be enhancing the nutrient content in the euphotic zone and thus causing occasionally increased surface productivity and enhancement in fluxes recorded in the sediment traps. However even in this case, the percentage of crustal matter is significant $(45 \%$; Fig. 8), although it is not related to any identified Saharan 
(a)

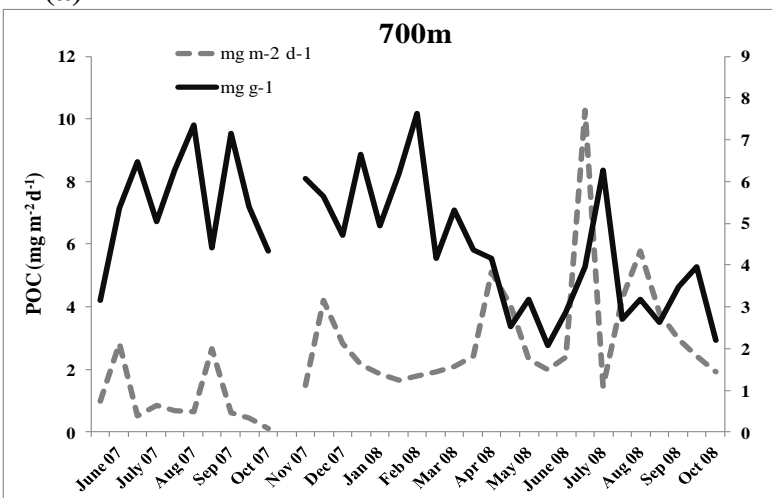

(b)

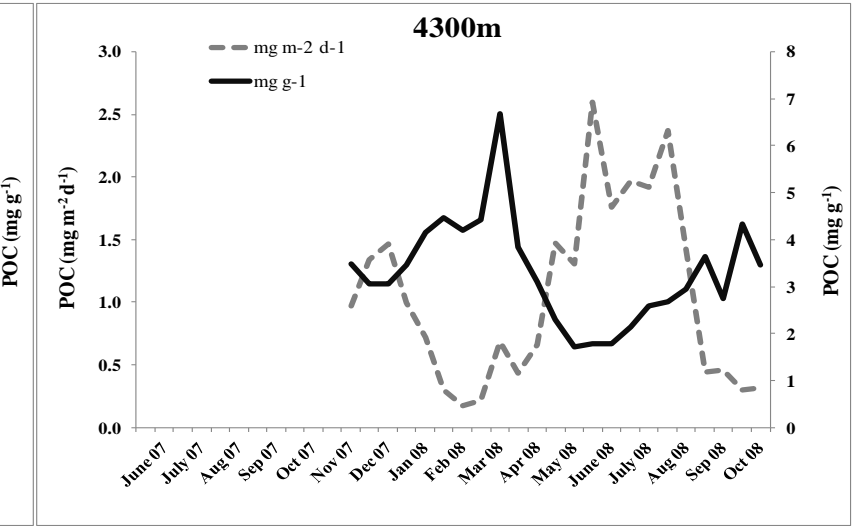

(c)

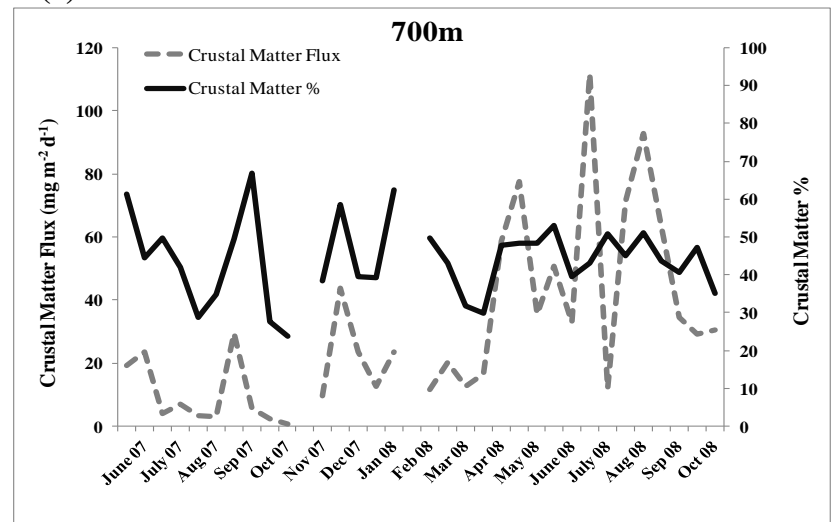

(d)

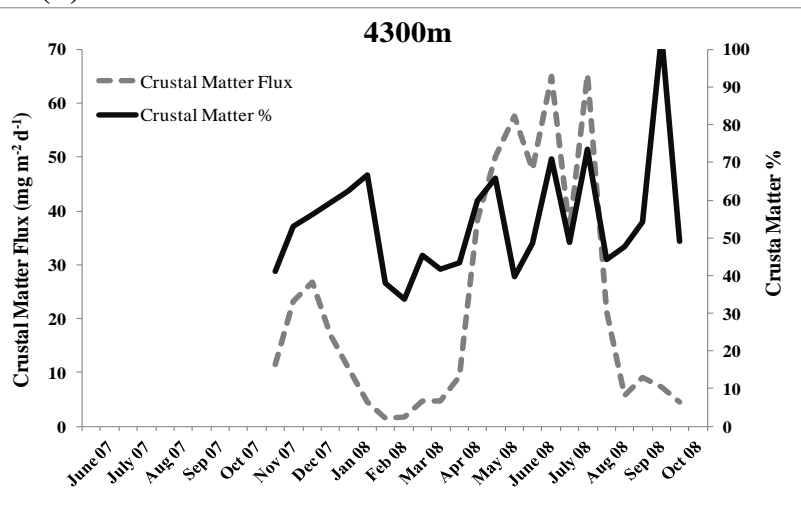

Fig. 8. Time series of particulate organic carbon $(\mathbf{a}, \mathbf{b})$ in both fluxes $\left(\mathrm{mg} \mathrm{m}^{-2} \mathrm{~d}^{-1}\right)$ and concentrations $\left(\mathrm{mg} \mathrm{g}^{-1}\right)$ and crustal matter $(\mathbf{c}, \mathbf{d})$ in both fluxes $\left(\mathrm{mg} \mathrm{m}^{-2} \mathrm{~d}^{-1}\right)$ and percentages (\%) at two depths; $700 \mathrm{~m}$ and $4300 \mathrm{~m}$.

event. Atmospheric mineral particles deposited during previous months and stored in the surface layers (Migon et al., 2002), acting as ballast in organic aggregates or incorporated into faecal pellets could be a possible explanation.

\section{Conclusions}

Chemical species described in this study, related to sinking particulate matter captured by sediment traps deployed at five successive depths (700 m to $4700 \mathrm{~m}$ ), at Nestor Site (Ionian Sea) from May 2007 to October 2008 reflect contribution from both natural and anthropogenic sources in the deep Ionian Sea basin. According to this, crustal-originated elements (Al, Fe and $\mathrm{Mn}$ ) and elements characteristic of anthropogenic sources ( $\mathrm{V}, \mathrm{Ni}, \mathrm{Cd}$ and $\mathrm{Pb}$ ) presented the same seasonal variability, suggesting that the common transport mechanism to the sampling site is atmospheric deposition. Molecular profile and diagnostic ratios of PAHs indicate a contribution from both unburned fossil fuels (petroleum) and combustion/pyrolytic PAHs in shallow and deep waters of the study area, deriving from multiple sources such as wood, coal and petroleum combustion along with petroleum residues during the summer of 2008, with elemental carbon particle association being a major driving force for pyrolytic PAHs export in surface waters.

Fluxes of all chemical species, decreased from the surface towards the deeper water layers of the Ionian Sea. In addition to vertical fluxes, lateral transport of particulate matter is recorded during certain periods at the near-bottom trap, most probably related to the influence of deep Adriatic water masses reaching the deep layers of the study site.

The evident covariance between all measured species reveals a common transport mechanism driven by the seasonal succession of planktonic species, crustal matter and anthropogenic inputs. Export fluxes are associated to a combination of forcings, namely external inputs of mineral matter and/or vertical mixing. The important Saharan dust input event of April 2008 could explain the simultaneous increase in mass flux observed in April 2008 at $700 \mathrm{~m}$ and down to $4300 \mathrm{~m}$ in May 2008, emphasizing the role of dust as a ballasting agent. The second marine mass flux maximum in May-June 2008, although not related to an identified dust event and rather 
associated to an upwelling of intermediate waters, enhancing the nutrient content in the euphotic zone, contains a significant amount of crustal material. Atmospheric mineral particles deposited during previous months, stored in the surface layers and acting as ballast in organic aggregates or incorporated into faecal pellets, could be a possible explanation for such behavior.

Finally, forest fire emissions were found to undergo a rapid (less than 15 days), and significant transport and deposition to the deep basins of the Eastern Mediterranean Sea during the summer fires of 2007 in western and southern Peloponnese, Greece, through association with atmospherically transported charcoal elemental (black) carbon emitted during the forest fire.

Acknowledgements. This work has been supported by KM3NET IP (EU/FP6) and HERMIONE IP (EU/FP7) projects. Many thanks to the officers and crew of R/V Aegaeo (Hellenic Centre for Marine Research, Greece) for their precious help during deployments and recoveries of the sediment traps. We would also like to thank G. Kambouri and I. Stavrakaki for the preliminary treatment of sediment trap samples. The authors want to thank C. Migon and L. Heimbürger for their helpful comments. C. Theodosi and N. Mihalopoulos acknowledge financial support from EU IP project Perseus (Grant agreement 287600).

Edited by: R. Danovaro

\section{References}

Adachi, K. and Tainosho, Y.: Characterization of heavy metal particles embedded in tire dust, Environ. Internat., 30, 1009-1017, doi:10.1016/j.envint.2004.04.004, 2004.

Birch, M. E. and Cary, R. A.: Elemental carbon-based method for monitoring occupational exposures to particulate diesel exhaust, Aerosol Sci. Tech., 25, 221-241, 1996.

Bouloubassi, I., Méjanelle, L., Pete, R., Fillaux, J., Lorre, A., and Point, V.: PAH transport by sinking particles in the open Mediterranean Sea: A 1 year sediment trap study, Mar. Pollut. Bull., 52, 560-571, doi:10.1016/j.marpolbul.2005.10.003, 2006.

Bruland, K. W., Donat, J. R., and Hutchins, D. A.: Interactive influences of bioactive trace metals on biological production in oceanic waters, Limnol. Oceanogr., 36, 1555-1577, 1991.

Castro-Jiménez, J., Berrojalbiz, N., Wollgast, J., and Dachs, J.: Polycyclic aromatic hydrocarbons (PAHs) in the Mediterranean Sea: Atmospheric occurrence, deposition and decoupling with settling fluxes in the water column, Environ. Pollut., 166, 40-47, doi:10.1016/j.envpol.2012.03.003, 2012.

Chester, R., Nimmo, M., Murphy, K. J. T., and Nicolas, E.: Atmospheric trace metals transported to the western Mediterranean: data from a station on Cap Ferrat. In Water Pollution Research Reports, vol.20, edited by: Martin, J. M. and Barth H., Commission of the European Communities, 597-612, 1990.

Dachs, J. and Eisenreich, S. J.: Adsorption onto aerosol soot carbon dominates gas-particle partitioning of polycyclic aromatic hydrocarbons, Environ. Sci. Tech., 34, 3690-3697, doi:10.1021/es991201+, 2000.
Dachs, J., Bayona, J. M., Fowler, S. W., Miquel, J. C., and Albaigés, J.: Vertical fluxes of polycyclic aromatic hydrocarbons and organochlorine compounds in the western Alboran Sea (southwestern Mediterranean), Mar. Chem., 52, 75-86, 1996.

Dachs, J., Lohmann, R., Ockenden, W. A., Méjanelle, L., Eisenreich, S. J., and Jones, K. C.: Oceanic biogeochemical controls on global dynamics of persistent organic pollutants, Environ. Sci. Tech., 36, 4229-4237, doi:10.1021/es025724k, 2002.

Deyme, R., Bouloubassi, I., Taphanel-Valt, M. H., Miquel, J. C., Lorre, A., Marty, J. C., and Méjanelle, L.: Vertical fluxes of aromatic and aliphatic hydrocarbons in the Northwestern Mediterranean Sea, Environ. Pollut., 159, 3681-3691, doi:10.1016/j.envpol.2011.07.017, 2011.

Fisher, N. S., Nolan, C. V., and Fowler, S. W.: Scavenging and retention of metals by zooplankton fecal pellets and marine snow, Deep Sea Research Part A, Oceanog. Res. Pap., 38, 1261-1275, 1991.

Fowler, S. W.: Trace elements in zooplankton particulate products, Nature, 269, 51-53, doi:10.1038/269051a0, 1977.

Gogou, A.: Study of the biogeochemical cycle of natural and anthropogenic organic compounds in northeastern Mediterranean region, $\mathrm{PhD}$ thesis, University of Crete, Greece, 160-163, 1998.

Gogou, A., Stratigakis, N., Kanakidou, M., and Stephanou, E. G.: Organic aerosols in Eastern Mediterranean: Components source reconciliation by using molecular markers and atmospheric back trajectories, Org. Geochem., 25, 79-96, doi:10.1016/s01466380(96)00105-2, 1996.

Gogou, A. I., Apostolaki, M., and Stephanou, E. G.: Determination of organic molecular markers in marine aerosols and sediments: One-step flash chromatography compound class fractionation and capillary gas chromatographic analysis, J. Chromatogr. A, 799, 215-231, doi:10.1016/s0021-9673(97)01106-0, 1998.

Guerzoni, S., Chester, R., Dulac, F., Herut, B., Loÿe-Pilot, M. D., Measures, C., Migon, C., Molinaroli, E., Moulin, C., Rossini, P., Saydam, C., Soudine, A., and Ziveri, P.: The role of atmospheric deposition in the biogeochemistry of the Mediterranean Sea, Prog. Oceanogr., 44, 147-190, doi:10.1016/s00796611(99)00024-5, 1999.

Guieu, C., Loÿe-Pilot, M. D., Ridame, C., and Thomas, C.: Chemical characterization of the Saharan dust end-member: Some biogeochemical implications for the western Mediterranean Sea, J. Geophys. Res. D, 107, 5-1-5-11, doi:10.1029/2001jd000582, 2002.

Gustafsson, Ö., Haghseta, F., Chan, C., Macfarlane, J., and Gschwend, P. M.: Quantification of the dilute sedimentary soot phase: Implications for PAH speciation and bioavailability, Environ. Sci. Technol., 31, 203-209, doi:10.1021/es960317s, 1997.

Heimbürger, L. E., Migon, C., Dufour, A., Chiffoleau, J. F., and Cossa, D.: Trace metal concentrations in the North-western Mediterranean atmospheric aerosol between 1986 and 2008: Seasonal patterns and decadal trends, Sci. Total Environ., 408, 2629-2638, 2010.

Heimbürger, L.E., Migon, C., and Cossa, D.: Impact of atmospheric deposition of anthropogenic and natural trace metals on Northwestern Mediterranean surface waters: A box model assessment, Environ. Pollut., 159, 1629-1634, 2011.

Heimbürger, L. E., Cossa, D., Thibodeau, B., Khripounoff, A., Mas, V., Chiffoleau, J. F., Schmidt, S., and Migon, C.: Natural and anthropogenic trace metals in sediments of the Ligurian 
Sea (Northwestern Mediterranean), Chem. Geol., 291, 141-151, doi:10.1016/j.chemgeo.2011.10.011, 2012.

Herut, B., Zohary, T., Krom, M. D., Mantoura, R. F. C., Pitta, P., Psarra, S., Rassoulzadegan, F., Tanaka, T., and Frede Thingstad, T.: Response of East Mediterranean surface water to Saharan dust: On-board microcosm experiment and field observations, Deep-Sea Res. Pt. II, 52, 3024-3040, doi:10.1016/j.dsr2.2005.09.003, 2005.

Heussner, S., Ratti, C., and Carbonne, J.: The PPS 3 time-series sediment trap and the trap sample processing techniques used during the ECOMARGE experiment, Cont. Shelf Res., 10, 943958,1990

Heussner, S., Durrieu de Madron, X., Calafat, A., Canals, M., Carbonne, J., Delsaut, N., and Saragoni, G.: Spatial and temporal variability of downward particle fluxes on a continental slope: Lessons from an 8-yr experiment in the Gulf of Lions (NW Mediterranean), Mar. Geol., 234, 63-92, doi:10.1016/j.margeo.2006.09.003, 2006.

Jickells, T.: Atmospheric inputs of metals and nutrients to the oceans: Their magnitude and effects, Mar. Chem., 48, 199-214, doi:10.1016/0304-4203(95)92784-p, 1995.

Koçak, M., Theodosi, C., Zarmpas, P., Séguret, M. J. M., Herut, B., Kallos, G., Mihalopoulos, N., Kubilay, N., and Nimmo, M.: Influence of mineral dust transport on the chemical composition and physical properties of the Eastern Mediterranean aerosol, Atmos. Environ., 57, 266-277, doi:10.1016/j.atmosenv.2012.04.006, 2012.

LaFlamme, R. E. and Hites, R. A.: The global distribution of polycyclic aromatic hydrocarbons in recent sediments, Geochimica et Cosmochimica Acta, 42, 289-303, 1978.

Lampitt, R. S., Bett, B. J., Kiriakoulakis, K., Popova, E. E., Ragueneau, O., Vangriesheim, A., and Wolff, G. A.: Material supply to the abyssal seafloor in the northeast Atlantic, Prog. Oceanogr., 50, 27-63, doi:10.1016/s0079-6611(01)00047-7, 2001.

Lipiatou, E. and Saliot, A.: Fluxes and transport of anthropogenic and natural polycyclic aromatic hydrocarbons in the western Mediterranean Sea, Mar. Chemi., 32, 51-71, 1991.

Lipiatou, E., Marty, J. C., and Saliot, A.: Sediment trap fluxes of polycyclic aromatic hydrocarbons in the Mediterranean Sea, Mar. Chem., 44, 43-54, 1993.

Lough, G. C., Schauer, J. J., Park, J. S., Shafer, M. M., Deminter, J. T., and Weinstein, J. P.: Emissions of metals associated with motor vehicle roadways, Environ. Sci. Technol., 39, 826-836, doi:10.1021/es048715f, 2005.

Mara, P., Mihalopoulos, N., Gogou, A., Daehnke, K., Schlarbaum, T., Emeis, K. C., and Krom, M.: Isotopic composition of nitrate in wet and dry atmospheric deposition on Crete in the eastern Mediterranean Sea GB4002, Global Biogeochem. Cy., 23, 10.1029/2008gb003395, 2009.

Martin, J. H. and Fitzwater, S. E.: Iron deficiency limits phytoplankton growth in the north-east Pacific sub arctic. Nature 331, 341343,1988

Martin, J. H., Gordon, R. M., and Fitzwater, S. E.: Iron in Antarctic waters, Nature, 345, 156-158. 1990.

Martín, J., Sanchez-Cabeza, J. A., Eriksson, M., Levy, I., and Miquel, J. C.: Recent accumulation of trace metals in sediments at the DYFAMED site (Northwestern Mediterranean Sea), Mar. Pollut. Bull., 59, 146-153, doi:10.1016/j.marpolbul.2009.03.013, 2009.
Migon, C., Sandroni, V., Marty, J. C., Gasser, B., and Miquel, J. C.: Transfer of atmospheric matter through the euphotic layer in the northwestern Mediterranean: Seasonal pattern and driving forces, Deep-Sea Res. Pt. II, 49, 2125-2141, doi:10.1016/s09670645(02)00031-0, 2002.

Neff, J.: Polycyclic Aromatic Hydrocarbons. Sources, fates and biological effects, Appl. Sci. Publ., London, 262 pp., 1979.

NTP (National Toxicology Program): 10th Report on carcinogens, US Department of Health and Human Services, Public Health Service, Washington, DC, 2002.

Parinos C., Gogou A., Bouloubassi I., Stavrakakis S., Plakidi E., and Hatzianestis, I.: Sources and downward fluxes of polycyclic aromatic hydrocarbons in the open southwestern Black Sea, Org. Geochem., 57, 65-75, 2013.

Passow, U.: Switching perspectives: Do mineral fluxes determine particulate organic carbon fluxes or vice versa?, Geochemistry, Geophysics, Geosystems, 5, Q04002, doi:10.1029/2003gc000670, 2004.

Pio, C., Cerqueira, M., Harrison, R. M., Nunes, T., Mirante, F., Alves, C., Oliveira, C., Sanchez de la Campa, A., Artíñano, B., and Matos, M.: OC/EC ratio observations in Europe: Rethinking the approach for apportionment between primary and secondary organic carbon, Atmos. Environ., 45, 6121-6132, doi:10.1016/j.atmosenv.2011.08.045, 2011.

Ramdahl, T.: Retene - a molecular marker of wood combustion in ambient air, Nature, 306, 580-582, 1983.

Raoux, C., Boyona, J. M., Miquel, J. C., Teyssie, J. L., Fowler, S. W., and Albaigés, J.: Particulate fluxes of aliphatic and aromatic hydrocarbons in near-shore waters to the northwestern Mediterranean Sea, and the effect of continental runoff, Estuarine, Coast. Shelf Sci., 48, 605-616, doi:10.1006/ecss.1998.0458, 1999.

Ridame, C. and Guieu, C.: Saharan input of phosphate to the oligotrophic water of the open western Mediterranean sea, Limnol. Oceanogr., 47, 856-869, 2002.

Roussiez, V., Heussner, S., Ludwig, W., Radakovitch, O., Durrieu de Madron, X., Guieu, C., Probst, J. L., Monaco, A., and Delsaut, N..: Impact of oceanic floods on particulate metal inputs to coastal and deep-sea environments: a case study in the NW Mediterranean Sea, Cont. Shelf Res., 45, 15-26, 2012.

Salma, I. and Maenhaut, W.: Changes in elemental composition and mass of atmospheric aerosol pollution between 1996 and 2002 in a Central European city, Environ. Pollut., 143, 479-488, doi:10.1016/j.envpol.2005.11.042, 2006.

Samanta, S. K., Singh, O. V., and Jain, R. K.: Polycyclic aromatic hydrocarbons: Environmental pollution and bioremediation, Trends Biotechnol., 20, 243-248, doi:10.1016/s01677799(02)01943-1, 2002.

Saydam, A. C. and Senyuva, H. Z.: Deserts: Can they be the potential suppliers of bioavailable iron?, Geophys. Res. Lett., 29, 19-11-19-13, 2002.

Schlitzer, R.: Ocean Data View, http://odv.awi.de, 2011.

Stavrakakis, S. and Lykousis, V.: Interannual mass flux variations of settling particles in the NESTOR basins, SE. Ionian Sea (E. Mediterranean), Greece, Nuclear Instruments and Methods in Physics Research, Section A: Accelerators, Spectrometers, Detectors and Associated Equipment, 626/627, S99-S101, doi:10.1016/j.nima.2010.04.076, 2011.

Stavrakakis, S., Gogou, A., Krasakopoulou, E., Karageorgis, A. P., Kontoyiannis, H., Rousakis, G., Velaoras, D., Perivoliotis, L., 
Kambouri, G., Stavrakaki, I., and Lykousis, V.: Downward fluxes of sinking particulate matter in the deep Ionian Sea (NESTOR site), Eastern Mediterranean: seasonal and interranual variability, Biogeosciences Discuss., 10, 591-641, doi:10.5194/bgd-10-5912013, 2013.

Sternbeck, J., Sjödin, A., and Andréasson, K.: Metal emissions from road traffic and the influence of resuspension - Results from two tunnel studies, Atmos. Environ., 36, 4735-4744, doi:10.1016/s1352-2310(02)00561-7, 2002.

Ternon, E., Guieu, C., Loÿe-Pilot, M.-D., Leblond, N., Bosc, E., Gasser, B., Miquel, J.-C., and Martín, J.: The impact of Saharan dust on the particulate export in the water column of the North Western Mediterranean Sea, Biogeosciences, 7, 809-826, doi:10.5194/bg-7-809-2010, 2010.

Theodosi, C., Markaki, Z., and Mihalopoulos, N., Iron Speciation, solubility and temporal variability in wet and dry deposition in the Eastern Mediterranean, Mar. Chem., 120, 100-107, 2010a.

Theodosi, C., Im, U., Bougiatioti, A., Zarmpas, P., Yenigun, O., and Mihalopoulos, N.: Aerosol chemical composition over Istanbul, Sci. Total Environ., 408, 2482-2491, doi:10.1016/j.scitotenv.2010.02.039, 2010b.

Theodosi, C., Markaki, Z., Tselepides, A., and Mihalopoulos, N.: The significance of atmospheric inputs of soluble and particulate major and trace metals to the eastern Mediterranean seawater, Mar. Chem., 120, 154-163, doi:10.1016/j.marchem.2010.02.003, 2010c.

Theodosi, C., Stavrakakis, S., Koulaki, F., Stavrakaki, I., Moncheva, S., Papathanasiou, E., Sanchez-Vidal, A., Koçak, M., and Mihalopoulos, N.: The significance of atmospheric inputs of major and trace metals to the Black Sea, J. Mar. Syst., 109/110, 94-102, 2013.

Tsapakis, M. and Stephanou, E. G.: Polycyclic aromatic hydrocarbons in the atmosphere of the Eastern Mediterranean, Environ. Sci. Technol., 39, 6584-6590, doi:10.1021/es0505321, 2005.
Tsapakis, M., Apostolaki, M., Eisenreich, S., and Stephanou, E. G.: Atmospheric deposition and marine sedimentation fluxes of polycyclic aromatic hydrocarbons in the eastern Mediterranean basin, Environ. Sci. Technol., 40, 4922-4927, doi:10.1021/es060487x, 2006.

Turquety, S., Hurtmans, D., Hadji-Lazaro, J., Coheur, P. F., Clerbaux, C., Josset, D., and Tsamalis, C.: Tracking the emission and transport of pollution from wildfires using the IASI CO retrievals: Analysis of the summer 2007 Greek fires, Atmos. Chem. Phys., 9, 4897-4913,doi: 10.1029/2002JD003186, 2009.

UNEP/MAP/MEDPOL: Sub-regional assessment of the Status of Marine and Coastal Ecosystems and of Pressures to the Marine and Coastal Environment Eastern Mediterranean Sea, 3738, 2010.

Venkatesan, M. I.: Occurrence and possible sources of perylene in marine sediments-a review, Mar. Chem., 25, 1-27, 1988.

Wakeham, S. G., Schaffner, C., and Giger, W.: Polycyclic aromatic hydrocarbons in Recent lake sediments. I. Compounds having anthropogenic origins, Geochimica et Cosmochimica Acta, 44, 403-413, 1980.

Weckwerth, G.: Verification of traffic emitted aerosol components in the ambient air of Cologne (Germany), Atmos. Environ., 35, 5525-5536, doi:10.1016/s1352-2310(01)00234-5, 2001.

Wedepohl, H.: The composition of the continental crust, Geochimica et Cosmochimica Acta, 59, 1217-1232, 1995.

Yunker, M. B., Macdonald, R. W., Vingarzan, R., Mitchell, R. H., Goyette, D., and Sylvestre, S.: PAHs in the Fraser River basin: A critical appraisal of PAH ratios as indicators of PAH source and composition, Org. Geochem., 33, 489-515, doi:10.1016/s01466380(02)00002-5, 2002.

Yunker, M. B., Macdonald, R. W., Snowdon, L. R., and Fowler, B. R.: Alkane and PAH biomarkers as tracers of terrigenous organic carbon in Arctic Ocean sediments, Org. Geochem., 42, 11091146, 2011. 